University of Michigan Law School University of Michigan Law School Scholarship Repository

Articles

Faculty Scholarship

2016

\title{
The Pendulum Swings: Reconsidering Corporate Criminal Prosecution
}

David M. Uhlmann

University of Michigan Law School, duhlmann@umich.edu

Available at: https://repository.law.umich.edu/articles/1760

Follow this and additional works at: https://repository.law.umich.edu/articles

Part of the Administrative Law Commons, Antitrust and Trade Regulation Commons, Business Organizations Law Commons, and the Criminal Law Commons

\section{Recommended Citation}

Uhlmann, David M. "The Pendulum Swings: Reconsidering Corporate Criminal Prosecution." UC Davis L. Rev. 49, no. 4 (2016): 1235-83.

This Article is brought to you for free and open access by the Faculty Scholarship at University of Michigan Law School Scholarship Repository. It has been accepted for inclusion in Articles by an authorized administrator of University of Michigan Law School Scholarship Repository. For more information, please contact mlaw.repository@umich.edu. 


\title{
The Pendulum Swings: Reconsidering Corporate Criminal Prosecution
}

\author{
David M. Uhlmann*
}

Corporate crime continues to occur at an alarming rate, yet disagreement persists among scholars and practitioners about the role of corporate criminal prosecution. Some argue that corporations should face criminal prosecution for their misconduct, while others would reserve criminal prosecution for individual corporate officials. Perhaps as a result of this conflict, there has been a dramatic increase over the last decade in the use of deferred prosecution and non-prosecution agreements for some corporate crimes, even as the government continues to bring criminal charges for other corporate crimes. To move beyond our erratic approach to corporate crime, we need a better understanding of what is accomplished by the criminal prosecution of corporations, a construct that considers retributive and utilitarian theories but also takes into account the expressive function of criminal law and the societal need for condemnation, accountability, and justice when crime occurs.

In this article, I provide a justification for corporate criminal prosecution that identifies the moral content of corporate crime, considers the deterrent value of corporate prosecution, and explains why the expressive value of the criminal law is indispensable in the corporate context. Corporate wrongdoing has pernicious effects on our communities, the economy, and the environment, which warrant the condemnation the criminal law provides. Criminal prosecution of corporations upholds the rule of law, validates the choices of law-abiding companies, and promotes

* Copyright (C) 2016 David M. Uhlmann. Jeffrey F. Liss Professor from Practice and the Director of the Environmental Law and Policy Program at the University of Michigan Law School. I would like to thank Brandon Garrett, Sam Gross, Vic Khanna, Nina Mendelson, Virginia Murphy, and Steve Ratner for their comments on drafts of the article, as well as my students David Park and Andrew Podrygula. I also would like to thank the participants in the research brown bag lunch series at the University of Michigan Law School and the Wharton Legal Studies and Business Ethics seminar series at the University of Pennsylvania. I am indebted to Samantha Kirby for her superb research assistance and Seth Quidachay Swan for outstanding library services. 
accountability. Together those values contribute to our sense that justice has been done when crime occurs, which enhances trust in the legal system, provides the opportunity for societal catharsis, and allows us to move forward in the aftermath of criminal activity. When corporations face no consequences for their criminal behavior, we minimize their lawlessness, and increase cynicism about the outsized influence of corporations.

\section{TABLE OF CONTENTS}

INTRODUCTION ............................................................ 1237

I. CRITIQUES OF CORPORATE CRIMINAL PROSECUTION .............. 1244

A. The Retributive Critique of Corporate Criminal Liability. 1245

B. The Utilitarian Critique of Corporate Criminal Liability. 1251

II. THE EXPRESSIVE FUNCTION OF CORPORATE CRIMINAL

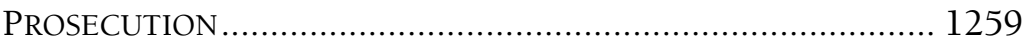

A. The Line-Drawing and Norm-Setting Functions of Corporate Criminal Liability.....

B. Societal Condemnation of Corporate Criminal Punishment............................................................... 1264

C. Societal Catharsis of Corporate Criminal Prosecution ..... 1267

III. THE MiSUNDERSTOOD RELATIONSHIP BETWEEN THE PROSECUTION OF CORPORATIONS AND INDIVIDUALS

A. Charging Both the Corporation and Culpable Individuals 1272

B. Charging the Corporation and Management Officials ..... 1275

C. Charging the Corporation and Lower-Level Supervisors .. 1277

D. Charging the Corporation and No Individuals 


\section{INTRODUCTION}

For more than a decade, the Justice Department morphed its approach to corporate crime, eschewing criminal prosecutions in favor of deferred prosecution and non-prosecution agreements that allowed large corporations to avoid the ignominy of criminal convictions. ${ }^{1}$ The trend began during the Bush administration and became so dominant during the Obama administration that the Criminal Division of the Justice Department entered deferred prosecution and non-prosecution agreements in more than two-thirds of the corporate cases it resolved between 2010 and 2012. ${ }^{2}$ There seemingly were no crimes that did not qualify for corporate absolution. The Justice Department entered a non-prosecution agreement in the Upper Big Branch mine disaster that killed twenty-nine miners, even though the Labor Department found that the mine owner had committed over 300 egregious violations of federal mine safety laws. ${ }^{3}$ The Justice Department agreed to a deferred prosecution with HSBC, even though the bank was involved in nearly a trillion dollars of money laundering, much of it from drug trafficking. ${ }^{4}$ There were no prosecutions at all — deferred or otherwise - for the worst financial crisis since the Great Depression, even though financial institutions and officials within those companies took unnecessary risks and engaged in conduct that imperiled the global economy. ${ }^{5}$

1 In a deferred prosecution agreement, criminal charges are filed but eventually dismissed if the corporation complies with the terms of the agreement; in a non prosecution agreement, criminal charges are never even filed if the company meets its obligations under the agreement. David M. Uhlmann, Deferred Prosecution and Non Prosecution Agreements and the Erosion of Corporate Criminal Liability, $72 \mathrm{MD}$. L. REV. 1295, 1301 n.43 (2013) [hereinafter Erosion of Corporate Criminal Liability].

2 It is difficult to overstate the surge in deferred and non prosecution agreements and the shift away from criminal prosecution of corporations. From 1992 to 2004, the Justice Department entered 26 deferred and non prosecution agreements, an average of just over two per year. From 2004 to 2012, the Department entered 242 deferred and non prosecution agreements, an average of just over 30 per year. Between 2010 and 2012, the Criminal Division entered twice as many deferred prosecution and non prosecution agreements as plea agreements. David M. Uhlmann, Op Ed., Prosecution Deferred, Justice Denied, N.Y. TIMES, Dec. 14, 2013, at A23.

3 Uhlmann, Erosion of Corporate Criminal Liability, supra note 1 at 1295 300; David M. Uhlmann, Op Ed., For 29 Dead Miners, No Justice, N.Y. TIMES, Dec. 9, 2011, at A25 [hereinafter 29 Dead Miners].

4 Uhlmann, Erosion of Corporate Criminal Liability, supra note 1 at 133738.

5 See, e.g., Sewall Chan, Financial Crisis Was Avoidable, Inquiry Finds, N.Y. TIMES, Jan. 26, 2011, at Al (describing the events leading up to the financial crash and the subsequent reports issued after a federal inquiry); Crash Course: The Origins of the Financial Crisis, ECONOMIST (Sept. 7, 2013), http://www.economist.com/news/ 
Then, with public alarm increasing over the lack of criminal prosecutions for the financial crisis, ${ }^{6}$ the pendulum swung, and criminal prosecutions were back in vogue. In 2014, the Justice Department brought record-setting criminal prosecutions against the European banks Credit Suisse and BNP Paribas for currency manipulation. ${ }^{7}$ Similar prosecutions followed during 2015 against JP Morgan Chase and Citicorp - apparently no longer "too big to jail" - as well as Barclays, Royal Bank of Scotland, and UBS. ${ }^{8}$ Volkswagen will likely face criminal charges for using defeat devices to conceal motor vehicle emissions violations, even though Toyota Motor Company and General Motors received deferred prosecutions for concealing motor vehicle safety violations during 2014 and $2015 .{ }^{9}$

To be fair, some parts of the Justice Department never stopped prosecuting corporate crime. The Environment and Natural Resources Division, historically the source of the largest number of corporate

schoolsbrief/21584534 effects financial crisis are still being felt five years article (discussing generally the history of the financial crisis). See generally THE FIN. CRISIS INQUIRY COMM'N, THE FINANCIAL CRISIS INQUIRY REPORT (2011), available at http://fcic.law.stanford.edu/report (outlining the findings of the commission created to examine the financial crisis).

6 See Jed S. Rakoff, The Financial Crisis: Why Have No High Level Executives Been Prosecuted?, N.Y. REV. BOOKS (Jan. 9, 2014), http://www.nybooks.com/articles/ archives/2014/jan/09/financial crisis why no executive prosecutions/. See also Court E. Golumbic \& Albert D. Lichy, The "Too Big to Jail" Effect and the Impact on the Justice Department's Corporate Charging Policy, 65 HASTINGS L.J. 101, 12326 (2014) (observing that, in aftermath of financial crisis, Justice Department has been under pressure to address wrongdoing at financial institutions amidst public perception that criminal conduct caused crisis); Daniel C. Richman, Corporate Headhunting, 8 HARv. L. \& Pol'y ReV. 265, 27880 (2014) (noting demand for criminal prosecutions and recognizing that they may have value but not as a substitute for regulatory reform to prevent similar financial crises in the future).

7 Ben Protess \& Jessica Silver Greenberg, Big Swiss Bank Pleads Guilty in Felony Case, N.Y. Times, May 20, 2014, at A1; Ben Protess \& Jessica Silver Greenberg, BNP Admits Guilt and Agrees to Pay $\$ 8.9$ Billion Fine to U.S., N.Y. TIMES, July 1, 2014, at B1.

8 Michael Corkery \& Ben Protess, Banks Admit Scheme to Rig Currency Price, N.Y. Times, May 21, 2015, at Al.

9 Compare Del Quentin Wilber \& Greg Farrell, Volkswagen Said Focus of U.S. Criminal Probe on Emissions, BloOMBerg Bus. (Sept. 21, 2015, 5:16 PM), http://www.bloomberg.com/news/articles/2015 09 21/volkswagen said to be target of u s criminal probe on emissions, with Bill Vlasic \& Matt Apuzzo, Toyota Is Fined $\$ 1.2$ Billion for Concealing Safety Defects, N.Y. TIMES, Mar. 20, 2014, at B1, and Danielle Ivory \& Bill Vlasic, $\$ 900$ Million Penalty for G.M.'s Deadly Defect Leaves Many Cold, N.Y. TIMES, Sept. 18, 2015, at B1. For a critique of the GM deferred prosecution agreement, see David M. Uhlmann, Op Ed., Justice Falls Short in G.M. Case, N.Y. TIMES, Sept. 20, 2015, at SR5. 
prosecutions, ${ }^{10}$ entered only two deferred prosecutions in the seventeen years between 1993 and 2009; the Antitrust Division, the source of the third largest amount of corporate prosecutions, entered only three deferred prosecutions during the same timeframe. ${ }^{11}$ Still, the Criminal Division employs the largest number of prosecutors in the Justice Department and is responsible for its most high-profile matters. Ambivalence within the Criminal Division about whether corporations should be prosecuted for their crimes - across two ideologically disparate administrations - suggests uncertainty about the role of corporate criminal prosecution.

The legal basis for imposing criminal liability on corporations is well-settled. Corporations are criminally liable for the acts of their employees or agents, committed within the scope of the employment or agency, for the benefit of the corporation. ${ }^{12}$ The corporation must act with the mental state required by the statute in question, which involves imputing the mental state of individual employees or agents to the corporation. ${ }^{13}$ In cases where no corporate employee or agent possesses the requisite mental state, however, criminal liability may be imposed based on the collective knowledge of the corporate employees or agents. ${ }^{14}$ It is not a defense for a corporation to argue that the conduct was not authorized by the board or officers of the corporation. ${ }^{15}$ Nor is it a defense to argue that the conduct was prohibited by official policies of the corporation or even the express instructions of supervisors. ${ }^{16}$

10 Environmental crimes historically are the subject matter of the largest number of corporate prosecutions. See Brandon L. Garrett, Globalized Corporate Prosecutions, 97 VA. L. ReV. 1775, 1873 (2011) [hereinafter Globalized Corporate Prosecutions].

11 Uhlmann, Erosion of Corporate Criminal Liability, supra note 1, at 131819 (citing U.S. Gov't ACCOUNTABILITY OfFICE, CORPORATE CRIME 15 nn.29 \& 35 (2009)).

12 N.Y. Cent. \& Hudson River R.R. v. United States, 212 U.S. 481, 494 (1909). New York Central requires the first two elements: (1) acts of employees or agents; and (2) committed within the scope of the employment or agency. Subsequent decisions have added for the benefit of the corporation as a way of ensuring that the conduct is within the scope of the employment or agency. See, e.g., United States v. Potter, 463 F.3d 9, 25 (1st Cir. 2006). The employee or agent acts for the benefit of the corporation even if the employee or agent acts for her own benefit, as long as the employee or agent acts at least in part to benefit the corporation. United States v. Automated Med. Labs, Inc., 770 F.2d 399, 407 (4th Cir. 1985).

13 United States v. Bank of New England, 821 F.2d 844, 856 (1st Cir. 1987) (citing Steere Tank Lines, Inc. v. United States, 330 F.2d 719, 722 (5th Cir. 1964)).

$14 \mathrm{Id}$. at 856.

15 United States v. Hilton Hotels, 467 F.2d 1000, 1004 (9th Cir. 1972) (citations omitted).

$16 \mathrm{Id}$. 
What then explains the conflicted approach to criminal prosecution of corporations - and what does it reveal about the theoretical basis for corporate criminal liability? A cynical response would be that the revolving door between Criminal Division leadership and white-collar law firms leads to a lack of resolve about the need to prosecute corporations. ${ }^{17}$ Perhaps there is greater willingness among career prosecutors to prosecute corporations, but my sense is that the political leadership of the Justice Department is faithful to its law enforcement mission and wants to bring high-profile cases when the law and the facts allow. A more nuanced view is that the Justice Department's erratic approach reflects a lack of agreement among practitioners about what is accomplished by the criminal prosecution of corporations, a disagreement that also exists in scholarly accounts of corporate criminal liability focusing on retributive and utilitarian purposes of punishment. ${ }^{18}$

Critics of corporate prosecution argue that there is no retributive purpose served by criminal punishment of corporations. They assert that criminal prosecution should be reserved for individuals, since corporate entities have no moral capacity. ${ }^{19}$ In addition, they claim that prosecuting corporations punishes shareholders and employees who had no role in the wrongdoing. ${ }^{20}$ From a utilitarian perspective, the critique focuses on the fact that the sanctions for corporate misconduct - monetary penalties and structural reforms - are the same regardless of whether the punishment occurs as the result of

17 See, e.g., Ben Protess, Once More Through the Revolving Door for Justice's Breuer, N.Y. Times, Mar. 28, 2013, at B6.

18 See infra Part I.

19 See, e.g., Daniel R. Fischel \& Alan O. Sykes, Corporate Crime, 25 J. Legal Stud. 319, 320 (1996) ("Corporations are legal fictions, and legal fictions cannot commit criminal acts. Nor can they possess mens rea, a guilty state of mind. Only people can act and only people can have a guilty state of mind."). This view is not so settled among moral philosophers. See generally Business Ethics: 2.1 Is the Corporation a Moral Agent?, StANFORd ENCYClOPEdiA OF PHIL. (Apr. 16, 2008), http://plato.stanford.edu/ entries/ethics business/\#CorMorAge (describing debate over whether corporations are moral actors independent of individuals that comprise the corporation).

20 Fischel \& Sykes, supra note 19 at 349 ("[I]n the case of a corporation, the burden of a punitive award will fall primarily on the shareholders, most of whom usually have no connection to the wrongdoing in question."); see also Albert W. Alschuler, Two Ways to Think About the Punishment of Corporations, 46 AM. CRIM. L. REV. 1359, 136769 (2009) [hereinafter Two Ways] ("The penalties imposed on innocent shareholders and employees when corporations are convicted are not incidental, collateral, or secondary. They are what the punishment of a collective entity is all about."). 
criminal or civil enforcement. ${ }^{21}$ This deterrence-based argument gains credence based on economic analysis suggesting that criminal enforcement may be less effective in promoting future compliance efforts, because companies are not incentivized to disclose and address wrongdoing if criminal prosecution (as opposed to civil enforcement) might ensue. ${ }^{22}$

Supporters of corporate prosecution argue that criminal enforcement is an essential tool to promote compliance with the law. ${ }^{23}$ They insist that there is a retributive role for corporate punishment, since wrongdoing in the corporate context deserves censure just as much as it does where individual conduct is involved. ${ }^{24}$ Moreover, when the corporation benefits from the misconduct, it cheats against its competitors; corporate misconduct therefore should be considered blameworthy in a moral and retributive sense. From a utilitarian perspective, advocates of corporate prosecution concede that the sanctions may be similar but assert that the deterrent effect of criminal punishment is necessarily greater than civil punishment, both because of the reputational harm imposed by criminal prosecution and the collateral consequences that may result from a criminal conviction. ${ }^{25}$

My view is that both corporations and individuals must be held accountable when misconduct occurs in the corporate setting. ${ }^{26}$ From a practical standpoint, corporate wrongdoing has a pernicious effect that warrants the use of all available tools to address it. The notion that criminal and civil sanctions are indistinguishable is belied by my experience as a federal prosecutor, including seven years as the Chief

21 See, e.g., V.S. Khanna, Corporate Criminal Liability: What Purpose Does It Serve?, 109 HARV. L. REV. 1477, 1534 (1996) ("[S]ome justification for corporate criminal liability may have existed in the past, when civil enforcement techniques were not well developed, but from a deterrence perspective, very little now supports the continued imposition of criminal rather than civil liability on corporations.").

22 See Jennifer Arlen, The Potentially Perverse Effects of Corporate Criminal Liability, 23 J. LEGAL STUD. 833, 86667 (1994).

23 See, e.g., Sara Sun Beale, A Response to the Critics of Corporate Criminal Liability, 46 AM. CRIM. L. REv. 1481, 148286 (2009) (arguing that "[b]ecause of their size, complexity, and control of vast resources, corporations have the ability to engage in misconduct that dwarfs" that of individuals, such that corporations must also be held accountable).

24 See id. at 1485.

25 See Samuel W. Buell, The Blaming Function of Entity Criminal Liability, 81 IND. L.J. 473, 50003 (2006) [hereinafter Blaming Function of Entity Criminal Liability] (examining what deterrence for entities may result from reputational harm); Uhlmann, Erosion of Corporate Criminal Liability, supra note 1, at 1335 (explaining what collateral consequences may result from criminal prosecution).

26 Uhlmann, Erosion of Corporate Criminal Liability, supra note 1, at 129596. 
of the Justice Department's Environmental Crimes Section, when corporate officials and their attorneys uniformly insisted that they would prefer civil enforcement to criminal prosecution. ${ }^{27}$ From a theoretical perspective, there are both retributive and utilitarian justifications for corporate criminal punishment. I would suggest that corporations are moral actors, with the capacity to act intentionally and to do good or evil, despite the fact that they do not have consciences, beliefs, or desires like individuals. ${ }^{28} \mathrm{I}$ also assert that there is additional deterrent value associated with criminal charges against corporations. Companies do not want to be labeled corporate criminals and therefore may have more incentives to avoid criminal sanctions than otherwise comparable civil or administrative sanctions. ${ }^{29}$

Yet the focus on retributive and utilitarian justifications - both in practice and in academia - obscures the expressive function of the criminal law and the societal need for condemnation, accountability, and justice when crime occurs. As Joel Feinberg explained with regard to the prosecution of individuals, ${ }^{30}$ an essential role of the criminal law is to make clear what conduct is outside the bounds of acceptable behavior and to express societal condemnation of unlawful conduct. ${ }^{31}$ The criminal law imposes blame and provides accountability for illegal behavior. ${ }^{32}$ The criminal law also validates the choices made by those who comply with the law by imposing punishment upon those who break the law. When criminal violations occur but are ignored or addressed by non-criminal alternatives, we obscure the line that the

27 As Chief of the Environmental Crimes Section, I was responsible for approving all charging decisions in cases prosecuted by my office, including hundreds of cases involving charges against corporations.

28 Uhlmann, Erosion of Corporate Criminal Liability, supra note 1, at 1333 34; see Lawrence Friedman, In Defense of Corporate Criminal Liability, 23 HARV. J.L. \& PuB. POL'Y 833, 84651 (2000) (examining how unique viewpoints, attitudes and moral judgments are attributed to corporations).

29 I acknowledge that corporate officials may be most incentivized to comply with the law by the prospect that they could go to jail if they engage in wrongdoing. David M. Uhlmann, After the Spill Is Gone: The Gulf of Mexico, Environmental Crime, and the Criminal Law, 109 MiCH. L. Rev. 1413, 1443 (2011) [hereinafter After the Spill] (explaining that the possibility of incarceration is more likely to result in corporation's compliance).

30 Joel Feinberg, The Expressive Function of Punishment, 49 MONIST 397 (1965).

31 See John L. Diamond, The Crisis in the Ideology of Crime, 31 IND. L. REV. 291, 311 (1998) [hereinafter Crisis in the Ideology of Crime].

32 See generally Buell, Blaming Function of Entity Criminal Liability, supra note 25, at 49294 (showing how individuals blame and hold entities accountable for their illegal actions). 
criminal law draws between acceptable and unacceptable behavior. When we do not condemn criminal behavior in the strongest possible terms, we risk minimizing or, worse, condoning lawlessness. ${ }^{33}$

The expressive function of the criminal law plays an even more essential role in the corporate context. First, we confer significant benefits on corporations with the expectation - indeed, the mandate - that corporations exist for legal purposes alone. When a corporation exploits those benefits and violates the public trust by engaging in illegal conduct, we must make clear that its behavior is unacceptable and condemn its conduct as criminal. Second, corporations have outsized power and influence in our society. When a corporation abuses that power and influence by committing crimes, we must impose blame, require accountability, and insist upon acceptance of responsibility. Third, corporations can neither be jailed nor have their individual liberties restricted when they commit crimes. The distinctive feature of corporate criminal prosecution is its ability to label corporate lawlessness as criminal, which is qualitatively different than labeling misconduct as a civil or administrative violation and critical to assuring society that corporate criminals are brought to justice.

In this Article, I will offer a more complete account of corporate criminal liability that incorporates retributive and utilitarian purposes, while emphasizing the expressive function of the criminal law and the broader societal values served by corporate criminal prosecution. Part I will consider the critiques of corporate criminal liability from both retributive and utilitarian perspectives. I will argue that there are retributive and utilitarian justifications for corporate criminal liability, even if those accounts may be incomplete. Part II will explain why the expressive function of criminal liability, whether viewed as a standalone proposition or an expansion of retributive and utilitarian theories, is essential to our understanding of the justification for corporate criminal liability and punishment. I will suggest that the expressive value of criminal prosecution - and the societal catharsis that results - is the most indispensable quality of corporate prosecution. Part III will address the relationship between the prosecution of corporations and individuals, with a focus on corporate-only prosecutions, which some view as a failure of prosecutorial discretion. Those criticisms are misplaced. Far from undermining arguments for corporate criminal liability, "corporate

33 Dan Kahan, What Do Alternative Sanctions Mean?, 63 U. CHI. L. REV. 591, 598 (1996) [hereinafter Alternative Sanctions]. 
only" resolutions demonstrate why corporate prosecution plays a critical role in our criminal justice system.

\section{CRITIQUES OF CORPORATE CRIMINAL PROSECUTION}

Criminal law theorists focus on retributive and utilitarian justifications for the imposition of punishment. Retributive theory focuses on the moral content or wrongfulness of criminal behavior and justifies punishment based on the "just deserts" of the defendant. ${ }^{34}$ As Michael Moore explains, "Retributivism is the view that punishment is justified by the moral culpability of those who receive it. A retributivist punishes because, and only because, the offender deserves it." 35 Utilitarian theory focuses on the societal harm of criminal behavior and justifies punishment to the extent that it serves the greater good (i.e. provides societal benefits that exceed the harm to the defendant). ${ }^{36}$ A utilitarian punishes to promote compliance with the law and deter future wrongdoing by the defendant (specific deterrence) and others who might violate the law absent the consequences they would face for engaging in similar misconduct (general deterrence). ${ }^{37}$

The focus of retributive and utilitarian theory is the punishment of individuals, specifically how as an ethical matter society can justify the loss of life or liberty that may accompany criminal punishment. It therefore is not a surprise that neither theory provides a complete justification for corporate criminal liability; retributive and utilitarian theories were not developed with corporations in mind. Neither loss of life or liberty is at stake when companies are charged criminally, although the latter may be implicated when corporate officials are charged. ${ }^{38}$ Nonetheless, critics of corporate criminal liability rely on retributive and utilitarian theories to support their claims.

34 Id. at 593 ("The purpose of imprisonment ... is to make offenders suffer. The threat of such discomfort is intended to deter criminality, and the imposition of it to afford a criminal his just deserts.").

35 Michael S. Moore, The Moral Worth of Retribution, in RESPONSIBILITY, CHARACTER, AND the EMOTIONS: NeW ESSAYS IN MORAL PSYCHOlOGY 179 (Ferdinand Schoeman ed., 1987) (italics omitted).

36 See, e.g., Richard S. Frase, Punishment Purposes, 58 Stan. L. Rev. 67, 70 (2005) (describing the purposes and limitations of the utilitarian approach to punishment).

37 See id. at 7072.

38 Non criminal alternatives are often justified by concerns about collateral consequences for employees, shareholders, and customers. Claims that criminal prosecution could result in a "corporate death penalty" have been debunked, however, since companies almost never fail as a result of criminal prosecution. Gabriel H. Markoff, Arthur Andersen and the Myth of the Corporate Death Penalty: Corporate 
In this Part, I will assess the critiques of corporate criminal prosecution. Analytical fit issues aside, I will suggest that the critiques miss their mark: there are retributive and utilitarian purposes served by corporate criminal liability, even if a more complete justification for corporate criminal liability requires accounting for the expressive function of criminal punishment, which I will address in Part II.

\section{A. The Retributive Critique of Corporate Criminal Liability}

John Coffee's seminal article "No Soul to Damn: No Body to Kick": An Unscandalized Inquiry Into the Problem of Corporate Punishment 39 is often cited by critics who argue that corporations should not be prosecuted criminally because they are not moral actors deserving of punishment. ${ }^{40}$ Like many critics of corporate criminal liability, Professor Coffee worried that corporate penalties would largely be visited upon innocent third parties, including stockholders, bondholders, employees who were not involved in the misconduct, and even customers. ${ }^{41} \mathrm{He}$ also focused extensively on the limits of corporate criminal liability, arguing that prosecution of corporations might not deter misconduct by individual employees 42 and describing the "deterrence trap" that results because corporations cannot be

Criminal Convictions in the Twenty First Century, 15 U. PA. J. Bus. L. 797, 827 (2013) ("No public company convicted in the years 20012010 went out of business because of a federal criminal conviction. This result calls the conventional wisdom about the Andersen Effect into serious doubt.").

39 John C. Coffee, Jr., "No Soul to Damn: No Body to Kick": An Unscandalized Inquiry into the Problem of Corporate Punishment, 79 MiCH. L. REV. 386 (1981).

40 Examples of this critique include the following: Albert W. Alschuler, Ancient Law and the Punishment of Corporations: Of Frankpledge and Deodand, 71 B.U. L. REV. 307, 31112 (1991) ("[E]fforts to stigmatize aggregations of people, most of whom are blameless, are unjustified in principle...."); Buell, Blaming Function of Entity Criminal Liability, supra note 25, at 475 ("Criminal law scholars have doubted the doctrine's theoretical soundness, pointing to illogic in retribution toward objects and the impossibility of fitting liberal concepts about responsibility with nonhuman actors. Entity criminal liability, these arguments go, is a purely imputed form of fault that has little or nothing to do with blameworthiness. And the doctrine is concerned with the fault of something without free will or character that is, an apparition with "no soul to be damned and no body to be kicked."); Khanna, supra note 21, at 1479 80 ("[L]egal thinkers did not believe corporations could possess the moral blameworthiness necessary to commit crimes of intent."); John T. Byam, Comment, The Economic Inefficiency of Corporate Criminal Liability, 73 J. CRIM. L. \& CRIMINOLOGY 582, 58385 (1982) (arguing that retributive theory is inapplicable in corporate context because corporations cannot be morally blameworthy).

41 Coffee, supra note 39, at 40102.

42 Id. at 393. 
jailed and may not have sufficient capitalization to be deterred by monetary penalties. ${ }^{43}$

Significantly, however, Professor Coffee did not claim that corporations should not be prosecuted. Instead, as I do, Professor Coffee argued that prosecutors should focus both on corporations and their employees when confronting criminal behavior in the corporate setting. Coffee explained that "a dual focus on the firm and the individual is necessary. Neither can be safely ignored." 44 His concern was that a focus on corporate prosecution, without also pursuing charges against individuals, would not be sufficient to deter criminal activity in the corporate setting, and he advocated for the use of alternative corporate sanctions that might provide more effective deterrence to corporate actors than pure monetary penalties. ${ }^{45}$

Nonetheless, even if Professor Coffee were most concerned with the limitations of corporate criminal liability as a deterrent for wrongdoing, the retributive critique of corporate liability is well summarized by his "no soul to damn, no body to kick" moniker. If the purpose of criminal punishment is to impose sanctions based on the defendant's moral culpability, corporations only would be proper targets of criminal prosecution if they possess moral capacity. Corporations are persons under the law, which allows them to sue and be sued and permits the law to treat their conduct as criminal. ${ }^{46}$ But corporate personhood is a legal fiction: corporations are artificial, incorporeal persons with no "minds" of their own and, according to the retributive critique, no capacity to make moral choices. ${ }^{47}$ Stated differently, a corporation does not have moral capacity independent of the natural persons who are its employees, officers, and board members - or, in rare cases, own its stock. ${ }^{48}$

The individuals who work for a company have souls to damn: they have the mental capacity to choose whether to conform their conduct to societal norms and the free will to act morally or immorally. We could ascribe moral culpability to a corporation based on the moral

\footnotetext{
43 Id. at 390.

44 Id. at 410.

45 See id. at 41344 (arguing that equity fines, adverse publicity, integration of criminal and civil remedies, restitution, and corporate probation would increase corporate deterrence more effectively than monetary penalties alone).

46 See, e.g., 33 U.S.C. 1362(5) (2012) (including corporations in the definition of "person" under the Clean Water Act).

47 Byam, supra note 40, at 585 (citation omitted).

48 See Fischel \& Sykes, supra note 19, at 323 ("Corporations are webs of contractual relationships consisting of individuals who band together for their mutual economic benefit.").
} 
culpability of its employees or agents. ${ }^{49}$ After all, we allow individuals to act on behalf of the corporation, and we impose criminal liability on the corporation for the acts of its employees. Yet moral culpability may not transfer as readily as legal responsibility. We impose vicarious liability on a corporation based on the acts of an individual employee or agent, because the employee or agent acts within the scope of her employment at least in part for the benefit of the corporation. ${ }^{50}$ Yet that begs the question of whether we can attach moral culpability to the corporation based on the acts of that individual employee or agent. What if every other individual associated with the corporation ascribed to a different set of moral values? Would we still attribute the immoral choice of one individual to the entire corporate entity?

Perhaps it would be easier to ascribe moral culpability to a corporation based on the acts and resulting moral culpability of its board and its officers. If board members or officers of a company engage in criminal behavior, it is far easier to attribute their misconduct to the corporation. After all, they set policies and establish priorities on behalf of the corporation. Yet if we equate the moral culpability of board members and officers with the moral culpability of the corporation, we still are making a moral judgment about other corporate officials and employees who did not act improperly and may have had no such moral failings in their conduct. To limit the harmful effects of criminal punishment to those with moral culpability, retributivists would limit criminal liability and punishment to individual corporate officials who engage in wrongdoing and utilize non-criminal alternatives to penalize corporations. ${ }^{51}$

To the extent that the retributive critique depends upon the legal fiction of corporate personhood, Sara Sun Beale responds that "corporations are not fictions. Rather, they are enormously powerful, and very real, actors whose conduct often causes very significant harm both to individuals and to society as a whole." 52 Professor Beale observes that the power wielded by corporations is "enormous and unprecedented in human history" and that corporate misconduct -

49 Gerard E. Lynch, The Role of Criminal Law in Policing Corporate Misconduct, 60 LAW \& CONTEMP. PROBS. 23, 50 (1997) (corporate morality is an extension of the moral culpability of its human agents and thus corporations may be deserving of punishment).

50 N.Y. Cent. \& Hudson River R.R. v. United States, 212 U.S. 481, 494 (1909); United States v. Automated Med. Labs, 770 F.2d 399, 407 (4th Cir. 1985); United States v. Hilton Hotels, 469 F.2d 1000, 1004 (9th Cir. 1972).

51 Byam, supra note 40, at 58385.

52 Beale, supra note 23, at 1482 . 
the abuse of corporate power - causes substantial harm to individuals and society. ${ }^{33}$ She further explains that "corporations have the ability to engage in misconduct that dwarfs that which could be accomplished by individuals." 54

I too have argued that corporations possess an outsized ability to do both good or harm in our communities. ${ }^{55}$ We readily embrace the beneficial actions of corporations, from the production of goods and employment opportunities, to the innovation and technological advancement that are powerful drivers in our economy and that can improve our quality of life. If we recognize the potential of corporations to make positive contributions to our society, however, we must acknowledge that their actions can be harmful, and at times in dramatic ways. "Because of [its] sheer size, a corporate polluter can cause far more environmental harm than an individual. A company that makes unsafe products can create far greater public health risks." 56 Nor are these examples from environmental and consumer protection law exhaustive. Most corporations strive to meet their legal obligations and contribute in a positive way in our communities, but there always will be some companies that break the law and risk or cause great harm.

Yet even if the conduct of corporations can cause great harm, which might make their acts deserving of criminal punishment, an answer to the retributive critique still requires addressing the question of whether corporations can be morally culpable for their actions. That question, as it turns out, is not nearly as settled as the retributive critique suggests. To be sure, there is support for the proposition that only individuals have the capacity to act intentionally and that corporations lack the intentionality that provides the basis for moral capability. ${ }^{.7}$ But there also is support for the contrary view, namely that corporations have internal decision structures that allow corporations to act intentionally and therefore morally. 58

53 Id. at 1483.

54 Id. at 1484.

55 Uhlmann, Erosion of Corporate Criminal Liability, supra note 1, at 1334.

56 Id.

57 See John Ladd, Morality and the Ideal of Rationality in Formal Organizations, 54 MONIST 488, 500 (1970) (arguing that corporations are like machines and thus unable to comply with principles of morality); Manuel G. Velasquez, Why Corporations Are Not Morally Responsible for Anything They Do, 2 Bus. \& Prof. ETHICs J. 1, 9 (1983) (claiming that corporations only act through individuals and therefore lack agency).

58 See Denis G. Arnold, Corporate Moral Agency, 30 MidweSt STUD. PhiL. 279, 281 (2006) (concluding that corporations are capable of exhibiting intentionality and thus are properly understood to be moral agents); Peter A. French, The Corporation as a 
The argument that corporations can be moral agents is bolstered by the extent to which corporations make business decisions guided by ethical and moral principles. Many businesses adhere to the triplebottom line approach of corporate social responsibility, which emphasizes people, profits, and planet. ${ }^{59}$ Corporate advertising extols virtues such as equal opportunity, maximizing individual potential, and healing the planet. ${ }^{60}$ Indeed, we speak often of good companies: businesses that make quality products and provide quality services to their customers, treat their employees fairly and compensate them well, strive to meet or exceed their legal obligations, and contribute positively in their communities. We also recognize that there are bad companies: businesses that produce shoddy products, exploit their workers and the environment, and who place no emphasis on meeting legal obligations or being good corporate citizens. ${ }^{61}$ The positive and negative attributes that we associate with corporations may extend beyond ethics and morality but that does not alter the fact that there are good and not-so-good corporate citizens, which reflect underlying corporate ethics.

It also merits emphasis that corporations, which enjoy legal status independent of their individual officers and employees, also have independent corporate cultures. ${ }^{62}$ Some companies are known for

Moral Person, 16 AM. PHIL. Q. 207, 207 (1979) ("[C]orporations can be full fledged moral persons and have whatever privileges, rights and duties are, in the normal course of affairs, accorded to moral persons.").

59 See generally John Elkington, Cannibals with Forks: The Triple Bottom Line OF 21ST CENTURY BUSINESS (1999).

60 Super Bowl XLIX in February 2015 featured numerous advertisements that promoted societal values. See, e.g., Always, Always \#LikeAGirl Super Bowl XLIX, YOUTUBE (Feb. 1, 2015), https://www.youtube.com/watch?v=yIxA3o84syY (promoting gender equality); Microsoft, Microsoft Super Bowl Commercial 2015: Braylon O’Neill, https://www.youtube.com/watch?v=wLXRt qRBfU, YouTUBE (Feb. 1, 2015), (promoting stories of maximizing potential through technology); Microsoft, Microsoft Super Bowl Commercial 2015: Estella's Brilliant Bus, YOUTUBE (Feb. 1, 2015), https://www.youtube. com/watch? $\mathrm{v}=7 \mathrm{cw} 4 j \mathrm{mKQs0E}$ (same); Jeep, Official 2015 Jeep Super Bowl Commercial | Beautiful Lands I Jeep Renegade, YouTUBE (Feb. 1, 2015), https://www.youtube.com/ watch? $\mathrm{v}=\mathrm{j} 7 \mathrm{LbPd} z \mathrm{YrrE}$ (promoting environmental awareness and responsibility).

61 See, e.g., Pamela H. Bucy, Corporate Ethos: A Standard for Imposing Corporate Criminal Liability, 75 MinN. L. REV. 1095, 1180 (1991) ("[T]he corporate ethos test... will target only the morally culpable corporation for criminal prosecution. Thus, the corporations indicted will be the 'bad' corporations that have demonstrated an intent to violate the law."); Friedman, supra note 28, at 847 ("[W]e tend to speak of corporations as real entities... and to describe their personae as we would an individual's personality as staid or flexible, welcoming or cold, even good or bad") (internal quotation marks omitted).

62 See generally Gwendolyn Gordon, Culture in Corporate Law, or: A Black 
going "beyond compliance" in conducting their business affairs, while companies that break the law often are criticized for their poor compliance cultures. To be sure, those positive and negative compliance cultures - as well as the corporate culture in matters ranging from human resources to community engagement - are shaped by corporate leadership. Yet corporate cultures persist despite management changes and influence behavior of individuals within those corporations, much as corporate priorities often endure over time and affect how individuals within the corporation behave. If corporate cultures are ontologically distinct and influential, it would follow that corporations have agency and moral culpability distinct from that possessed by individuals within the company, in which case the retributive critique loses much of its force.

Of course, ethical and moral behavior of corporations exists on a continuum, much as it does for individuals. A corporation could engage in wrongdoing, whether because its management fails to devote sufficient resources to compliance or because its employees have not been trained sufficiently. The company may be a good company that has engaged in misconduct, much the same as an individual may have a moral lapse and engage in conduct that is not typical of her behavior. Prosecutors might exercise discretion and decline to charge aberrational behavior, and we might expect greater leniency in the face of isolated misconduct than for a pattern of misconduct.

But how prosecutors exercise their discretion with regard to corporate misconduct - and the degree to which they might find the underlying acts deserving of punishment - is a different question from whether corporations are morally culpable. Individuals do not have to be immoral in all of their actions to be morally culpable for their misconduct. Likewise, a corporation does not have to be immoral in all of its actions for it to be morally culpable for its misconduct. Under a retributive approach we properly focus on the defendant's moral culpability for the criminal act; we do not excuse or mitigate conduct if the defendant is otherwise morally upright. Even a corporation that is law-abiding in most other respects could be morally culpable for its crimes, if we accept the proposition that corporations have decision-making capacities and identities distinct from their individual agents. ${ }^{63}$

Corporation, a Christian Corporation, and a Maori Corporation Walk into a Bar . ., 39 Seattle U. L. Rev. 353 (2016).

63 An alternative view is that corporations are deserving of blame from a retributivist perspective, even if we cannot resolve the debate about their moral 


\section{B. The Utilitarian Critique of Corporate Criminal Liability}

My colleague Vic Khanna provides a classic utilitarian critique of corporate criminal liability in his article Corporate Criminal Liability: What Purpose Does It Serve? ${ }^{64}$ Professor Khanna argues that corporate criminal liability emerged as a vicarious liability doctrine in the early 1900s because civil penalties were not available to address corporate misconduct. ${ }^{65}$ His claim draws support from the Supreme Court decision in New York Central \& Hudson River Railroad Co. v. United States, 66 which rejected claims that corporations should not be immune from criminal prosecution because doing so "would virtually take away the only means of effectually controlling the subject-matter [interstate commercial transactions] and correcting the abuses aimed at [it]." 67 Of course, with the expansion of civil enforcement regimes in the intervening decades, there now are other ways to effectually control wrongful business practices. ${ }^{68}$

Professor Khanna therefore asks whether civil penalties can provide the same utilitarian benefits as criminal penalties and at a lower cost to society. Utilitarian goals of punishment include incapacitation, deterrence, and rehabilitation of criminal defendants. ${ }^{69}$ Incapacitation is not applicable in the corporate context, since it involves the incarceration of defendants to protect the public from harm, which is not an option for corporate defendants. Deterrence and rehabilitation both can be achieved by corporate criminal prosecution - deterrence by creating incentives for corporations to comply with the law and making it more costly to violate the law; rehabilitation by mandating corporate structural reforms, including corporate compliance programs, as terms of probation. ${ }^{70}$ Professor Khanna focuses on

agency, because corporate crime evinces a failure of corporate management regardless of whether they are involved in the wrongdoing. See Amy J. Sepinwall, Guilty by Proxy: Expanding the Boundaries of Responsibility in the Face of Corporate Crime, 63 HASTINGS L.J. 411, 451 (2012) [hereinafter Guilty by Proxy].

64 Khanna, supra note 21 , at 1478.

65 Id. at 148586.

66212 U.S. 481 (1909).

$67 \mathrm{Id}$. at 496.

68 See, e.g., 33 U.S.C. § 1319(a) (c) (2012) (establishing criminal, civil, and administrative penalties for violations of the Clean Water Act).

69 See Frase, supra note 36, at 70.

70 See Brandon L. Garrett, Structural Reform Prosecution, 93 VA. L. ReV. 853, 89091 (2007) (describing DOJ's goal of using prosecution to increase compliance, change corporate culture, and spur other structural reforms); Uhlmann, After the Spill, supra note 29, at 144852 (describing the deterrent effects of corporate criminal prosecution in the context of oil and drilling companies). 
deterrence and whether civil penalties might be just as effective as criminal penalties in promoting compliance and preventing violations. ${ }^{71}$

Under the economic approach that Professor Khanna supports, crime will be deterred efficiently if penalties are set at levels high enough to discourage unlawful behavior even when discounted for the likelihood that the violation will be detected by the government. ${ }^{72}$ Since the likelihood of detection is less than $100 \%$, penalties must be correspondingly greater than the cost of compliance. ${ }^{73}$ Otherwise, the rational economic actor might be better off saving money on compliance, especially when the risk of being caught if violations occur is low. But penalties cannot be set too high, particularly in a legal regime with vicarious liability, or socially desirable business activity will be chilled. ${ }^{74}$ If penalties are properly calibrated in this fashion, optimal deterrence should result. ${ }^{75}$

Professor Khanna considers monetary and reputational penalties as the primary tools for achieving optimal deterrence. Standing alone, civil fines and criminal fines offer the same deterrence inasmuch as they are monetized and reduced to the same degree by the applicable risk of detection. Professor Khanna acknowledges that the reputational harm of criminal penalties arguably might be greater than the stigma attached to civil penalties. ${ }^{76}$ Professor Khanna argues that monetary penalties are a more precise and efficient penalty, however, since we have no ability to determine accurately how much reputational

71 See Khanna, supra note 21, at 149394.

72 Accord Arlen, supra note 22, at 834 (discussing how the economic approach of corporate criminal liability sanctions the wrongdoer to deter crime); see Khanna, supra note 21, at 1533 ("A desirable system should permit the imposition of cash fines and supplementary sanctions, such as equity fines or a loss of license, when cash fines are insufficient.").

73 As previously noted, environmental crimes are the largest area of corporate criminal prosecution based on number of convictions. Garrett, Globalized Corporate Prosecutions, supra note 10, at 1873. Yet the United States Environmental Protection Agency has only 200 special agents, which makes it impossible to investigate all instances of environmental violations that might warrant criminal enforcement.

74 See Khanna, supra note 21, at 151416 ("[T] he possibility of a severe sanction under an uncertain legal standard may chill desirable behavior ...."); cf. Arlen, supra note 22 at 83536,843 (arguing that a strict vicarious liability regime may chill corporate detection and enforcement expenditures).

75 See, e.g., Fischel \& Sykes, supra note 19, at 34243 (claiming that "nothing was gained by prosecuting Exxon criminally" for the Exxon Valdez oil spill, and that "[c]ivil penalties against Exxon levied through the tort system were sufficient to achieve optimal deterrence").

76 Khanna, supra note 21, at 150809. 
damage will occur based on a criminal prosecution, conviction, and sentence. ${ }^{77}$ And, according to Professor Khanna, no one benefits from the reputational damage to a corporation, in contrast to a fine that can be used by the government for future enforcement efforts or other societal benefits. ${ }^{78}$ He therefore claims that a properly calibrated civil enforcement regime is preferable to criminal liability at least to the extent that deterrence is the objective. ${ }^{79}$

If one accepts the view that reputational harm and other nonmonetary sanctions can be monetized, Professor Khanna might be right that the deterrent value of civil penalties could equal the deterrent value of criminal penalties. Courts could increase the applicable civil fine by whatever amount were necessary to account for the reduced reputational damage and arrive at an enhanced civil fine that would have an equivalent deterrent effect as the criminal penalty. Yet, putting aside for now the question of whether the expressive value of criminal prosecution would warrant criminal liability - a view that Professor Khanna rejects - there are at least three challenges to relying solely on civil enforcement. ${ }^{80}$

First, civil penalties will only deter to the same degree as criminal penalties if civil penalties are at least as great if not larger than criminal penalties. As a theoretical matter, this might not be a challenge; as a practical matter, it could be insurmountable. In some areas of the law, civil penalties are comparable to potential criminal penalties. For example, although financial institutions were not prosecuted criminally for their roles in the financial crisis, JP Morgan Chase and Citigroup both paid multi-billion dollar civil penalties for their misconduct. ${ }^{81}$ In the Gulf oil spill, BP paid $\$ 20.8$ billion to resolve civil claims including $\$ 5.5$ billion in civil penalties - amounts that exceed the $\$ 4.5$ billion the company paid in criminal penalties. ${ }^{82}$

77 Id. at 150304 ("[W]e should prefer cash fines over reputational sanctions as long as the corporation is not judgment proof.").

78 Id. at 1503.

79 Id. at 1511.

80 See infra Part II for a discussion of the expressive value of corporate criminal prosecution.

81 Devlin Barrett \& Dan Fitzpatrick, J.P. Morgan, U.S. Settle for $\$ 13$ Billion, Wall ST. J. (Nov. 19, 2013), http://www.wsj.com/articles/ SB10001424052702304439804579207701974094982; Andrew Grossman \& Christina Rexrode, Citigroup to Pay $\$ 7$ Billion in Mortgage Probe, Wall St. J. (July 14, 2014), http://www.wsj.com/articles/citigroup to pay 7 billion to resolve mortgage probe 1405335864.

82 Kevin McGill, US Judge OKs \$20B Settlement from 2010 BP Oil Spill, Associated PRESS (Apr. 4, 2016), http://bigstory.ap.org/article/062ee20eed004fcf94f151f5fb29b8e7/us 
Yet criminal penalties can be as much as twice the gain or loss associated with a criminal offense, 83 which often would far exceed the available civil penalties. In the Gulf oil spill example, the maximum criminal penalty was more than $\$ 40$ billion based on the economic losses and natural resource damages associated with the spill. ${ }^{84}$ The maximum civil penalty for BP was $\$ 13$ billion - and for other companies was far lower. For worker safety, mine safety, consumer protection, food and drug, and wildlife violations, criminal penalties dwarf what would be available under civil penalty regimes.85 Of course, Congress could address these disparities, but it has not done so in the worker safety context for decades ${ }^{86}$ — and there are no civil penalties for arguably the oldest wildlife protection law, the Migratory Bird Treaty Act. ${ }^{87}$

Second, it may be a mistake to assume that reputational harm can be monetized and imposed instead as monetary fines. To the extent that lost business results, it might theoretically be possible to know ex ante the amount of those losses. In reality, it would almost never be

judge oks 20b settlement 2010 bp oil spill 0; Steven Mufson, BP Settlement Will Cost $\$ 20.8$ Billion, Justice Department Says, WASH. POST (Oct. 5, 2015), http://www.washingtonpost. com/business/economy/bp settlement will cost 208 billion justice department says/2015/ 10/05/abb82ble 6 b78 1le5 b31c d80d62b53e28 story.html. BP previously paid $\$ 4$ billion in criminal penalties to resolve Clean Water Act, Migratory Bird Treaty Act, manslaughter, and false statement charges based on the spill; the company paid an additional $\$ 500$ million to address securities violations. Judgment, United States v. BP Exploration \& Prod. Inc., No 2:12 CR 00292 (E.D. La. 2013).

83 See Alternative Fines Act, 18 U.S.C. $\& 3571$ (2012).

84 BP has paid approximately $\$ 14.7$ billion in economic losses and agreed to pay nearly $\$ 8$ billion in natural resource damages. See Gulf of Mexico Oil Spill Claims and Other Payments, Public Report, BRIT. PeTrOleum (July 31, 2015), http://www.bp. com/content/dam/bp country/en us/PDF/GOM/Public Report July 2015.pdf (regarding economic losses); Campbell Robertson, John Schwartz \& Richard Pérez Peña, \$18.7 Billion Deal Reached with BP in Gulf Oils Spill, N.Y. TimES (July 2, 2015), http://www.nytimes.com/2015/07/03/us/bp to pay gulf coast states 187 billion for deepwater horizon oil spill.html? $\mathrm{r}=0$ (regarding natural resource damages).

85 See, e.g., Mine, Safety and Health Act, 30 U.S.C. § 820 (2012) (addressing mine safety); Federal Insecticide, Fungicide, and Rodenticide Act, 7 U.S.C. § 1361 (2012) (covering food and drug violation penalties); Endangered Species Act, 16 U.S.C. § 1540 (2012) (protecting wildlife); see also David M. Uhlmann, Prosecuting Worker Endangerment: The Need for Stronger Criminal Penalties for Violations of the Occupational Safety and Health Act, ADVANCE: J. ACS IsSUE GROUPS, Spring 2009, at 191, 19596 [hereinafter Prosecuting Worker Endangerment] (stating that criminal penalties can be much higher than administrative penalties under the Occupational Safety and Health Act).

86 See Uhlmann, Prosecuting Worker Endangerment, supra note 85, at 201 (showing that criminal provisions of worker safety laws have not been amended since 1970s).

87 See 16 U.S.C. $\$ 707$ (2012). 
possible to predict lost business from reputational damage - and, given the number of factors that can contribute to lower revenues, it may not even be possible to assess reputational harm after the fact. ${ }^{88}$ For example, there is anecdotal evidence that consumers avoided using Exxon and BP gas stations after their oil spills but that their reluctance was not widespread, at least in part because "boycotts" are more likely to affect independent franchisees than oil producers. ${ }^{89} \mathrm{On}$ the other hand, the Volkswagen emissions scandal, at least for now, appears to have alienated some customers permanently. 90

Moreover, prospective uncertainty about how much lost business will occur has a deterrent value that a fixed penalty cannot provide. If a company has few competitors and inelastic demand for its product or services, lost business may be limited. In a competitive marketplace, however, and particularly one where demand for a company's product or services is elastic, lost business could be substantial. In those circumstances, corporations might seek to avoid the reputational harm of a criminal conviction in part because it is hard to know how much lost business would occur as a result. ${ }^{91}$

An economist might protest that uncertainty about reputational harm and resulting lost business leads to inefficient allocation of resources, since companies cannot determine what sanction they will face if they commit violations and are prosecuted. Yet that is precisely why reputational harm is a powerful deterrent. Just as we are more likely to comply with the law when we are afraid of getting caught like when we are careful about our speed because there might be a speed trap ahead - we are more likely to avoid violations when we are uncertain about how large any resulting penalties will be. When we are certain about the likelihood of detection and amount of punishment, the sanction becomes a price and loses deterrent value,

88 Buell, Blaming Function of Entity Criminal Liability, supra note 25, at 51012 (describing the many variables influencing reputational effect).

89 See Kate Sheppard, Should You Boycott BP?, Mother Jones (June 14, 2010), http://www.motherjones.com/blue marble/2010/06/should you boycott bp.

90 See, e.g., Richard Conniff, Revenge of the Jetta, N.Y. TIMES, Sept. 27, 2015, at SR5.

91 In the Volkswagen example, it remains to be seen how much the emissions scandal will hurt sales. The company reported a $2 \%$ decline in sales for 2015 , at least some of which was attributable to the emissions scandal. See David McHugh, German Automaker Volkswagen Says Global Sales Fell 2 Percent Last Year Amidst Emissions Scandal, U.S. NewS \& WORLD ReP. (Jan. 8, 2016), http://www.usnews. com/news/business/articles/2016 01 08/scandal hit volkswagen brand sees 2015 sales fall 48 pct. The extent to which sales rebound in 2016 and beyond will depend upon many variables, including the company's ability to recall and retrofit affected vehicles and whether lost sales are limited to VW vehicles or spread to other Volkswagen brands. 
which is particularly problematic in the criminal context where the optimal societal outcome is that no crime occurs.

Third, criminal enforcement may have the ability to change the culture of organizations in ways that civil penalties cannot. The stigma of a criminal conviction extends beyond reputational harm in the marketplace; it also extends to the internal dynamics of a corporation. I would suggest that criminal prosecution may have an effect in the board room and in the corporate suite in ways that civil enforcement does not. ${ }^{22}$ There are numerous examples of companies that paid civil penalties and continued to have compliance problems - until they were criminally prosecuted and then made far greater efforts to comply with the law. One example is the pipe manufacturing company McWane, Inc., which committed egregious worker safety and environmental violations for years, even after incurring civil penalties for its infractions, until it was prosecuted at five separate facilities and forced to pay more than $\$ 25$ million in criminal fines and penalties. ${ }^{93}$ Since the prosecution, McWane has invested extensive resources in worker safety and environmental compliance. ${ }^{94}$ Another example is Central Industries, which committed approximately 1114 permit violations, exceeding pollutant limitations in the company's Clean Water Act permit by hundreds of percentage points and its authorized flow rate by millions of gallons. ${ }^{95}$ Its misconduct continued for more than a decade, even though the company faced civil

92 Indeed, impacts may extend to lower level managers as well. Sally S. Simpson et al., An Empirical Assessment of Corporate Environmental Crime Control Strategies, $103 \mathrm{~J}$. CRIM. L. \& CRIminology 231, 239 (2013) ("Although the literature is slim and contradictory, there is evidence that firm level stigmatic consequences trickle down to responsible managers."); see Cindy R. Alexander, On the Nature of the Reputational Penalty for Corporate Crime: Evidence, 42 J.L. \& ECON. 489, 523 (1999); Jonathan M. Karpoff et al., The Cost to Firms of Cooking the Books, 43 J. Fin. \& Quantitative ANALYSIS 581, 60507 (2008) (discussing reputational penalties' effects on corporations).

93 See Uhlmann, Prosecuting Worker Endangerment, supra note 85, at 19697 (describing the investigation of McWane and the subsequent pleas and fines). Numerous individuals also were prosecuted for crimes at three of the facilities where McWane faced criminal charges. Id. at 197.

94 See A Dangerous Business Revisited, Frontline (Feb. 5, 2008), http://www.pbs. org/wgbh/pages/frontline/mcwane/etc/synopsis.html; McWane, EPA in Landmark Environmental Settlement, FOUNDRY MAG. (July 14, 2010), http://foundrymag.com/ meltpour/mcwane epa landmark environmental settlement.

95 United States v. Cent. Indus., Inc., No. 3:00CR18WS (S.D. Miss. 2000); see Press Release, U.S. Dep't of Justice, Central Industries, Inc. Pleads Guilty to 26 Felony Violations in Mississippi Water Pollution Case (Nov. 2, 2000) [hereinafter Central Industries Press Release], available at http://perma.law.harvard.edu/0uorDgBoVB1. 
penalties, until the company was prosecuted, pleaded guilty, and paid a $\$ 13$ million criminal fine and $\$ 1$ million in restitution. ${ }^{96}$

Criminal prosecution also may affect employee morale, retention, and recruitment in ways that civil penalties do not. While fines under criminal and civil regimes could be equalized, at least in theory, it is far less clear that a civil enforcement action could ever focus board, management, and employee attention on compliance to the same extent that criminal prosecution does. Criminal and civil enforcement are different in kind and different in their effects. Much as the societal message is different, as I discuss in Part II, the impact within a company and the resulting deterrence may be different, at least for specific deterrence of that company.

Other distinctions between criminal and civil enforcement may further increase the deterrent effects of corporate criminal liability. When companies plead guilty in criminal cases, as most corporate defendants do, they must admit their wrongdoing, ${ }^{97}$ which in many cases requires a senior corporate official to appear in court and admit to the company's misconduct. Civil settlements sometimes require similar admissions - most notably in some Securities and Exchange Commission actions - but the majority of civil settlements stipulate that the defendant "neither admits nor denies" wrongdoing.98 In addition to requiring greater accountability, as I discuss in Part II, admissions of wrongdoing - like the stigma of criminal conviction and punishment - may also focus companies on compliance more than civil settlements. ${ }^{99}$

Finally, criminal convictions have collateral consequences that increase their deterrent value. Perhaps the best-known example is the automatic disqualification for banks and other financial institutions that issue securities, which purportedly was the basis for deferred prosecution and non-prosecution of banks until the government

96 Central Industries Press Release, supra note 95.

97 Garrett, Globalized Corporate Prosecutions, supra note 10, at 1804 n.112 (noting that, in accordance with the Principles of Federal Prosecution of Business Organizations $\S 928.1300$, a corporation must provide enough facts showing its guilt when pleading guilty to prevent future assertions of innocence).

98 See Samuel W. Buell, Liability and Admissions of Wrongdoing in Public Enforcement of Law, 82 U. CIN. L. REV. 505, 51517 (2013) (describing how failing to require corporations to admit wrongdoing in civil settlements "squanders" the deterrence benefits of enforcement).

99 Admissions of wrongdoing also may increase the deterrent effects of criminal punishment, since corporations are collaterally estopped from denying the underlying conduct in any related civil lawsuits (and therefore may be more likely to incur liability and damages in those suits). See id. at 512. 
decided to grant waivers. ${ }^{100}$ Companies that are convicted of criminal violations also may face suspension or debarment from government contracting. For example, some environmental crimes, such as convictions under the Clean Water Act, impose mandatory loss of government contracts. ${ }^{101}$ Suspension and debarment is not part of the punishment for criminal violations; rather it serves remedial purposes. Companies are prohibited from entering new contracts with the government until they address the conditions that gave rise to their conviction. ${ }^{102}$ In the typical case, that means negotiating with the government over the terms of a compliance program that will prevent future violations. No suspension and debarment authority exists for civil violations nor would it be practical for civil violations to trigger loss of government contracting given the much larger number of civil violations that occur across all regulatory programs.

What emerges from this analysis is the view that criminal penalties are different than civil penalties, if not in the fines that they produce (which, at least in theory, could be equalized) but in the effect they have on organizations, the accountability they require, and the collateral consequences that result. Prosecutors must use care in how they impose criminal sanctions: as Jennifer Arlen notes, there are circumstances where the prospect of criminal prosecution reduces incentives for companies to audit their activities and correct and selfreport violations. ${ }^{103}$ In addition, there may be circumstances where criminal sanctions would cause harm to innocent third parties, such as the Wake Med case in North Carolina where criminal prosecution of a rural hospital would have jeopardized access to health care for elderly and poor residents who depended upon Medicare and Medicaid benefits. ${ }^{104}$ But the utilitarian critique of corporate criminal liability

100 Banks that commit criminal violations are ineligible issuers under Rule 405 of the Securities Act of 1933. JP Morgan Chase, Citigroup, Barclays, and Royal Bank of Scotland received disqualification waivers when they agreed to plead guilty to currency manipulation. See Michael Corkery \& Ben Protess, Banks Admit Scheme to Rig Currency Price, N.Y. Times, May 21, 2015, at Al.

10133 U.S.C. \& 1368(a) (2012) (prohibiting federal agencies from contracting with any person convicted under the Clean Water Act "until the [EPA] Administrator certifies that the condition giving rise to such conviction has been corrected").

102 Id.

103 Arlen, supra note 22, at 835 36, 843, 848.

104 Uhlmann, Erosion of Corporate Criminal Liability, supra note 1, at 132122. Collateral consequences to innocent third parties are the primary justification offered by the Justice Department for entering deferred prosecution and non prosecution agreements instead of seeking criminal convictions. Id. at 1320. But the Justice Department has not required its prosecutors to demonstrate that collateral consequences are present nor is there empirical evidence that significant collateral 
fails on its own terms. Deterrence is central to utilitarian theories of criminal punishment - and deterrence is greater when a company may be criminally liable for egregious misconduct, along with the corporate officials who may be liable as individuals.

\section{THE EXPRESSIVE FUNCTION OF CORPORATE CRIMINAL PROSECUTION}

Fifty years ago, Joel Feinberg wrote that criminal punishment was different from other kinds of penalties because of the "symbolic significance" of the criminal sanction. ${ }^{105}$ Professor Feinberg did not purport to be the first scholar to focus on the expressive function of punishment. Other moral philosophers, most notably Henry M. Hart, claimed that community condemnation was an essential feature of criminal punishment. ${ }^{106}$ As Professor Hart explained:

What distinguishes a criminal from a civil sanction and all that distinguishes it, it is ventured, is the judgment of community condemnation which accompanies... its imposition.... [A crime] is conduct which, if duly shown to have taken place, will incur a formal and solemn pronouncement of the moral condemnation of the community. ${ }^{107}$

Professor Feinberg went further than Professor Hart and argued that condemnation involved not only an expression of disapproval but also an expression of societal resentment. ${ }^{108} \mathrm{He}$ explained that society must express its disavowal of criminal conduct, make clear its nonacquiescence in impermissible behavior, vindicate the rule of law, and absolve the innocent. ${ }^{109}$

Scholars disagree about whether expressive theory is an independent justification for criminal punishment or merely a restatement of aspects of retributive or utilitarian theories. ${ }^{110}$ To the extent that condemnation reflects a societal judgment about the wrongfulness of behavior, expressive theory has a retributive quality. Societal condemnation also may have deterrent effects, inasmuch as

consequences have been avoided. See id. at 1322 .

105 Feinberg, supra note 30, at 400.

106 See id. at 401 (acknowledging the legal community's general acceptance of the idea that community condemnation is essential for punishment).

107 Henry M. Hart, Jr., The Aims of the Criminal Law, 23 Law \& Contemp. Probs. 401, 40405 (1958) (quoted in Feinberg, supra note 30, at 401).

108 Feinberg, supra note 30, at 403.

109 Id. at 40408.

110 See Kahan, Alternative Sanctions, supra note 33, at 601. 
defendants would want to avoid the associated stigma, which suggests a utilitarian quality. On the other hand, there is a degree to which both retributive and utilitarian theory are focused on the defendant's behavior and not on the societal messaging that accompanies criminal prosecution, which might indicate that expressive theory is a standalone justification for criminal liability and punishment.

My goal here is not to resolve the question of whether expressive theory is an independent justification for criminal punishment. Instead, I want to focus on how the values associated with expressive theory resonate in the analysis of the role of corporate criminal prosecution. I hope to expand understanding of the expressive function of corporate criminal prosecution beyond the concept of societal condemnation of the defendant, although I agree that is a key attribute of the expressive function. Criminal prosecution of corporations also reflects the societal imperative to respond to illegal behavior in a way that upholds the rule of law, reinforces core societal values, provides accountability, and ensures that justice has been done.

In this Part, I consider corporate criminal prosecution from an expressive perspective. ${ }^{111}$ First, I assess the degree to which corporate criminal liability involves line-drawing and norm-setting that is essential to upholding the rule of law and validates the choices of companies who meet their legal obligations. Second, I analyze societal condemnation as a sanction for unlawful behavior and how the stigma or shame that accompanies criminal punishment is particularly significant in the corporate context. Third, I address how accountability and the sense that justice has been done is necessary in the face of corporate wrongdoing - and how corporate criminal prosecution promotes the societal catharsis that must take place for us to move beyond the harmful effects of wrongdoing.

\section{A. The Line-Drawing and Norm-Setting Functions of Corporate Criminal Liability}

A central purpose of the criminal law is the expression of societal values about what conduct will not be tolerated. ${ }^{112}$ The criminal law

111 I will use the term "corporate criminal prosecution" to describe both corporate criminal liability and corporate criminal punishment. I refer to "corporate criminal liability" as the corporate misconduct that gives rise to criminal liability, which we might think of as a definitional question of what conduct is criminalized. I refer to "corporate criminal punishment" as the sanction we impose when corporate criminal liability is present. The two are related but analytically distinct concepts.

112 See Friedman, supra note 28, at 84243 ("Criminal liability in turn expresses the community's condemnation of the wrongdoer's conduct by emphasizing the standards 
performs this line-drawing function by delineating what conduct will give rise to criminal liability - and then reinforces the message by authorizing criminal punishment. In some instances, the criminal law sets a boundary between lawful and unlawful conduct. Bank robbery and kidnapping are crimes; there are no circumstances where robbing a bank or kidnapping another person involves lawful conduct. In other instances, the criminal law sets a boundary between types of unlawful conduct. It is unlawful to drive over the speed limit; speeding becomes criminal when it recklessly endangers others or if a death occurs because of the driver's negligent speeding.

The criminal law is not the only way that the law expresses societal values and demarcates between lawful and unlawful conduct. Civil laws also perform line-drawing functions that express societal values. For example, anti-discrimination laws prohibit employment discrimination based on race or gender, which helps ensure that all people are treated equally in employment decisions. ${ }^{113}$ Discrimination based on race or gender offends core societal values and, if proven, can result in substantial civil liabilities. We reserve criminal liability, however, for misconduct that is more egregious or is committed with a more culpable mental state - or both. If the same discriminatory animus results in intentionally causing bodily injury to another person, it becomes a hate crime and subjects the defendant to criminal prosecution. ${ }^{114}$ Both civil and criminal violations involve unlawful conduct, but criminal violations are qualitatively different or worse. As John Diamond explains, "what is criminally wrong and right must be something more than what is merely civilly wrong and right." 115

Corporate criminal liability provides the same line-drawing function as the criminal law does in other contexts. A broad array of rules governs the activities of corporations, including but not limited to labor, consumer safety, environmental, antitrust, securities, and tax laws. We expect companies to comply with all of these laws, and we may impose civil liability when they fail to meet their obligations. But

for appropriate behavior that is, the standards by which persons and goods properly should be valued."); Dan M. Kahan, Social Influence, Social Meaning, and Deterrence, 83 VA. L. REV. 349, 362 (1997) (arguing that positions that the criminal law takes are "suffused with meaning" about "what kind of life the community views as virtuous").

113 See, e.g., Title VII of the Civil Rights Act of 1964, 42 U.S.C. §§ 2000e 2000e 17 (2012) (prohibiting employer discrimination on the basis of race, sex, color, national origin, and religion).

11418 U.S.C. \& 249 (2012) (criminalizing certain offenses involving actual or perceived race, color, religion, or national origin).

115 Diamond, Crisis in the Ideology of Crime, supra note 31, at 309. 
some violations are more serious than others, not just in degree but in kind, which we express by imposing criminal liability. As a normative matter, we reserve criminal liability for the most egregious corporate misconduct, to express the societal view about what corporate behavior will not be tolerated under any circumstances. ${ }^{116}$

Of course, the normative proposition that we reserve corporate criminal liability for egregious violations may or may not be descriptive. There is substantial debate about whether we criminalize too much conduct in the United States, particularly in the regulatory context where most corporate crime occurs. ${ }^{117}$ On the other hand, there also are instances where our laws contain inadequate criminal provisions, such as the Occupational Safety and Health Act, ${ }^{118}$ which makes it a crime to commit a worker safety violation only if the defendant acts willfully and an employee dies. ${ }^{119}$ Knowing violations that result in death or willful violations that result in serious injuries only give rise to civil penalties. ${ }^{120}$ Resolving questions about what corporate misconduct should be criminalized is beyond the scope of this article, but the expressive function of corporate criminal liability highlights the need for criminal sanctions to focus on corporate

\footnotetext{
116 See id.

117 The House Judiciary Committee created a bipartisan task force on over criminalization in May 2013. Press Release, U.S. House of Representatives, House Judiciary Committee Creates Bipartisan Task Force on Over Criminalization (May 5, 2013), available at http://judiciary.house.gov/index.cfm/2013/5/ housejudiciarycommitteecreatesbipartisantaskforceonovercriminalization. The task force was reauthorized in February 2014. Press Release, U.S. House of Representatives, House Judiciary Committee Reauthorizes Bipartisan Over Criminalization Task Force (Feb. 5, 2014), available at http://judiciary. house.gov/index.cfm/2014/2/house judiciary committee reauthorizes bipartisan over criminalization task force. See also Erik Luna, The Overcriminalization Phenomenon, 54 AM. U. L. REV. 703, 712 (2005) (arguing that the government readily misuses crime and punishment); Paul S. Rosenzweig, The Over Criminalization of Social and Economic Conduct, 7 Heritage Found. Legal Memorandum, Apr. 17, 2003, at 812 (arguing that criminal law today punishes those who have no bad intent or actual knowledge of the law); cf. John L. Diamond, The Myth of Morality and Fault in Criminal Law Doctrine, 34 AM. CRIM. L. REv. 111, 112 (1996) ("[C]riminal law groups selective samples of the reprehensible with the innocent and effectively condemns both."); Stuart P. Green, Why It's a Crime to Tear the Tag Off a Mattress: Overcriminalization and the Moral Content of Regulatory Offenses, 46 EMORY L.J. 1533, 1535 (1997) (describing the increased use of criminal law in regulatory offenses and the potentially negative consequences).

118 Occupational Health and Safety Act, 29 U.S.C. §§ 651678 (2012).

11929 U.S.C. § 666 (2012).

120 Uhlmann, Prosecuting Worker Endangerment, supra note 85, at 19596.
} 
misconduct that is most egregious and warrants the strongest possible societal response.

The criminal law is our most powerful tool for expressing what conduct is outside the bounds of acceptable corporate behavior what I have referred to as the line-drawing function of corporate criminal liability. The criminal law also is our most powerful tool for expressing how we expect corporations to conduct their affairs what I call the norm-setting function of corporate criminal liability. The criminal provisions of the Clean Water Act provide an example of both functions. ${ }^{121}$ The Clean Water Act requires facilities that discharge pollutants into waters of the United States to obtain permits. ${ }^{122}$ Facilities must self-monitor their compliance with permit limits and submit discharge monitoring reports to the government. ${ }^{123}$ When the reports contain accurate information, regulators have reliable information about pollution activity and are better able to ensure that state water quality standards are satisfied. When the reports contain false information, the self-monitoring system created by the Clean Water Act is undermined and harmful pollution may go undetected. Criminal prosecution of corporations that submit false reports makes clear that it is unacceptable to mislead regulators about permit compliance - and reinforces the norm that companies are expected to be truthful in their communications with the government.

Corporate criminal liability thus becomes an essential tool for upholding the rule of law and reinforcing societal norms. We repudiate the choices made by companies who violate the law and ensure both that they do not profit from their misconduct but also that they cannot treat any resulting penalties as merely a "cost of doing business" (i.e. paying a price or fee to engage in the conduct). We validate the choices made by law-abiding companies, who must commit substantial resources to meet their legal obligations and should not be at a competitive disadvantage with companies who break the law.

Conversely, when we do not impose criminal liability upon corporations that commit egregious violations of the law, we blur the lines that the criminal law establishes between conduct that is

12133 U.S.C. \& 1319 (c) (2012).

12233 U.S.C. $\S \S 1311,1342,1344$ (2012).

12333 U.S.C. $\& 1318$ (2012) (requiring point source polluters to maintain records, make reports, and monitor their discharges); 40 C.F.R. $\S 122.41(\mathrm{j})$ (2015) (promulgating regulations for permittees to retain records that must include certain requirements); 40 C.F.R. $\& 122.48$ (2015) (requiring permits to specify the proper monitoring equipment, monitoring type, and reporting requirements). 
acceptable and conduct that will not be tolerated. We express to the companies that break the law that their conduct is not so egregious that it warrants criminal prosecution. We tell companies that are diligent about meeting legal obligations that their efforts are valued less by society. In the process, we weaken adherence to the rule of law and our ability to send societal messages about what corporate behavior is unacceptable and what corporate behavior we want to promote.

\section{B. Societal Condemnation of Corporate Criminal Punishment}

Corporate criminal liability expresses societal values about what corporate conduct to promote and what corporate conduct will not be tolerated. For the norm-setting and line-drawing of corporate criminal liability to be more than aspirational, however, criminal punishment must ensue when corporations commit egregious violations of the law. The societal condemnation that is expressed by criminal punishment is both the distinctive feature of the criminal sanction - as Professors Hart and Feinberg recognized ${ }^{124}$ — as well as the criminal law's unique tool for censuring corporate misconduct. We cannot jail a corporation, but we can condemn its conduct by treating it as criminal and imposing criminal punishment on the corporation.

The societal condemnation that accompanies corporate criminal punishment serves multiple purposes. First, societal condemnation offers a targeted, defendant-specific repudiation of the corporation's misconduct. Corporate criminal liability expresses societal values about what corporate conduct is unacceptable by prospectively defining certain categories of conduct as criminal. Corporate criminal punishment expresses societal views about the unacceptable conduct of a specific corporation by retrospectively condemning the criminal activity of the corporation. The laws defining corporate conduct as criminal have little meaning without the subsequent punishment of corporate defendants who violate the laws - and the accompanying societal condemnation of their misconduct.

Second, societal condemnation of corporate criminal behavior is a powerful sanction for the corporation. The labeling of corporate misconduct as criminal sullies the corporation's reputation as a lawabiding and ethical corporation. The company may lose business as a result, as discussed in Part I, but reputational harm is a broader sanction than lost business. Reputational harm can discourage investment in a company and make it more difficult to recruit and retain valued employees. Reputational harm also can hamper

124 See supra notes 10507 and accompanying text. 
relationships in the broader business community.125 Fines and lost business can be internalized by a corporation and may be viewed within the company - and by society - as a price for engaging in misconduct. Societal condemnation and the resulting reputational harm are sanctions that cannot be fully monetized and therefore can have more enduring effects.

Whether reputational harm persists for a long time or dissipates quickly will vary depending on the corporation involved and the nature of its misconduct. To some extent, the duration of the stigma of criminal prosecution will depend upon factors within the corporation's control, including the degree to which the corporation expresses remorse and takes steps to improve its compliance efforts. Stigma may nonetheless endure based on factors beyond the corporation's control, such as public perceptions of the wrongdoing and the extent to which corporate values are seen as the culprit. ${ }^{126}$ In the interim, the reputational harm of criminal prosecution can be significant for corporate management and employees. ${ }^{127}$ As noted in Part I, corporate officers must account to board members and shareholders about why the corporation engaged in criminal misconduct; 128 corporate employees must endure the ignominy of working for a corporation condemned as criminal.

Third, societal condemnation of corporate criminal behavior imposes blame on the corporations where misconduct occurs. Samuel Buell argues that the blaming function of what he terms "entity criminal liability" represents its central function. ${ }^{129}$ He observes that, as a matter of social psychology, organizations often influence individuals within their midst and therefore corporations (or corporate culture) often may be responsible for misconduct carried

125 But see Khanna, supra note 21, at 150012 (analyzing reputational sanctions and concluding such sanctions are "rarely socially desirable in the corporate context").

126 See supra notes 8991 and accompanying text.

127 See generally Buell, Blaming Function of Entity Criminal Liability, supra note 25 (discussing how constituents, consumers, and audiences take criminal sanctions seriously and find reputational effects very important).

128 BP chief executive officer Tony Hayward resigned in the wake of the Gulf oil spill. Eduard Gismatullin \& Brian Swint, BP's Hayward Quits After Spill Shreds Pledge to Improve Safety, BlOOMBERG BuS. (July 27, 2010), http://www.bloomberg.com/news/ articles/2010 07 27/hayward s resignation inevitable after bp spill undermined safety pledge. Volkswagen CEO Martin Winterkorn suffered a similar fate because of the VW emissions debacle. Jack Ewing, Rigged Testing by Volkswagen Fells Its C.E.O., N.Y. Times, Sept. 24, 2015, at Al.

129 Buell, Blaming Function of Entity Criminal Liability, supra note 25, at 477 ("[T]he blaming function of entity criminal liability is linked closely to the utility of the doctrine."). 
out by individuals within the corporation. ${ }^{130}$ When that relationship is present, Professor Buell proposes that it is proper to blame the corporation for criminal activity. ${ }^{131}$ He suggests that his proposal has retributive qualities, inasmuch as the corporation is deserving of sanction, and utilitarian benefits, because affixing blame on the organization may lead to changes that will prevent future wrongdoing - and may motivate other corporations to take steps to improve their corporate cultures. ${ }^{132}$

I agree with Professor Buell that the blaming function of corporate criminal prosecution is an effective expressive tool that vindicates societal interests in condemning wrongdoing. I also agree that there may be deterrent effects from imposing blame. To the extent that the corporation is to blame for the criminal wrongdoing of its employees - either because it condones misconduct or increases the likelihood that violations will occur because of insufficient compliance efforts and/or inadequate training - societal condemnation is appropriate. In my experience, as Professor Buell suggests, most corporate crimes are attributable to a poor compliance culture. ${ }^{133}$

Of course, if societal condemnation has substantial expressive benefits, it follows that when corporate wrongdoing occurs and is not prosecuted criminally there may be significant expressive costs. ${ }^{134}$ As I have argued elsewhere, when we sanction corporate misconduct with a deferred prosecution or civil penalties that do not involve the same degree of societal condemnation, we minimize corporate misconduct and may risk condoning it. ${ }^{135}$ When criminal sanctions are not sought, we express a societal judgment that the conduct is less egregious. "[W]hen society deliberately foregoes answering the wrongdoer

130 Id. at 49397 (describing how institutions shape behavior); see also Bucy, supra note 61, at 1127 (concluding that "(1) each corporation is distinctive and draws its uniqueness from a complex combination of formal and informal factors; (2) the formal and informal structure of a corporation can promote, or discourage, violations of the law; and (3) this structure is identifiable, observable, and malleable").

131 Buell, Blaming Function of Entity Criminal Liability, supra note 25, at 497 ("[O]ur blaming practice is rooted in the reality that, in the modern world, organizations do influence behavior.").

$132 \mathrm{Id}$. at 51622 (discussing retribution); id. at 50012 (discussing deterrence).

133 There is at least some empirical research to support these views. "Evidence suggests that managers who believe that the corporate culture is tolerant of illegality are more likely to violate regulations." Simpson et al., supra note 92, at 238.

134 See Gregory M. Gilchrist, The Expressive Cost of Corporate Immunity, 64 HAstings L.J. 1, 4951 (2012) (discussing how failure to impose criminal liability on corporations "risks sending the signal that criminal conduct will be punished except where it is committed by a corporation").

135 Uhlmann, Erosion of Corporate Criminal Liability, supra note 1, at 1336. 
through punishment, it risks being perceived as endorsing his valuations [and misconduct]."136 Non-criminal alternatives also express to those affected by the misconduct that any harm they suffered is less significant. Resulting cynicism about whether corporations are above the law erodes public confidence in our criminal justice system and thus compounds the harm wrought by corporate misconduct.

\section{Societal Catharsis of Corporate Criminal Prosecution}

Prior expressive accounts have focused to varying degrees on the normative role of corporate criminal liability and the stigma of societal condemnation - but not on how the presence or absence of corporate responsibility affects public perceptions of corporate misconduct and the fairness of the criminal justice system. I would argue that criminal prosecution of corporate misconduct is necessary to maintain public trust and to ensure that the criminal justice system promotes fairness even when misconduct involves the most powerful actors in our economy. When corporate crime is prosecuted, we are more able to move past wrongdoing, which I refer to as the process of "societal catharsis." When corporate crime is not addressed, the negative effects of corporate misconduct linger, sometimes indefinitely.

There is no doubt that corporate crime inflicts harm that must be addressed by the criminal justice system. In some cases, corporate crimes results in catastrophic harm. At the Upper Big Branch Mine in West Virginia, twenty-nine miners died because of egregious violations of the Mine Safety Act committed by Massey Corporation. ${ }^{137}$ In the Gulf oil spill, millions of barrels of oil gushed into the Gulf of Mexico causing incalculable harm to the environment and billions of dollars of economic losses. ${ }^{138}$ In the wake of preventable tragedies like the Upper Big Branch Mine disaster and the Gulf oil spill, we have a societal need to label the misconduct as criminal and condemn the corporate malfeasance in the strongest possible terms. ${ }^{139}$ We expect

\footnotetext{
136 Kahan, Alternative Sanctions, supra note 33, at 598.

137 Uhlmann, 29 Dead Miners, supra note 3. An investigation by the Mine Safety and Health Administration revealed over 300 violations of the Mine Safety and Health Act, 30 U.S.C. $\$ \S 801965$ (2012), at the Upper Big Branch Mine, including nine flagrant violations that contributed to the explosion and resulting deaths. U.S. DEP'T OF Labor, Mine SAFETy \& HeAlth Admin., Report of InVEstigation, FAtAl Underground Mine EXPLOSION 2, 15 (2010) [hereinafter "MSHA REPORT"], available at http://arlweb.msha.gov/Fatals/2010/UBB/FTL10c0331noappx.pdf.

138 Uhlmann, After the Spill, supra note 29, at 141416.

139 Uhlmann, Erosion of Corporate Criminal Liability, supra note 1, at 1336, 1343
} 
the corporations involved to admit that their conduct was criminal and to be held accountable by the criminal justice system, both so that justice is done and also so that we can collectively move on from the tragedies wrought by their corporate wrongdoing. ${ }^{140}$

The need for societal catharsis may be greatest when corporate crime results in tragedy, but I would suggest that it also is present in less heralded cases as well. Criminal activity tears at the social fabric that binds us together in society. ${ }^{141}$ An essential feature of the social contract is our collective agreement to adhere to the rule of law. To uphold the rule of law, we must sanction those who violate the law. We expect corporations to meet their legal obligations, just as we expect individuals to do so; we must sanction corporate criminality just as we must sanction individual criminality. ${ }^{142}$ By upholding the rule of law in the face of criminal activity, we begin to repair the harm to the social order caused by criminal conduct.

We facilitate societal catharsis in at least three other ways when we hold corporations responsible for their criminal behavior. First, the terminology that we use to describe the conduct matters both for its own sake and because it affects our collective sense that justice has been done. ${ }^{143}$ If the conduct involved is criminal, we should call it criminal. It does not become less criminal because the actor is a corporation. When we use non-criminal terms to describe criminal behavior by corporations, we fuel cynicism, undermine confidence in the justice system, and hinder societal healing. In contrast, when we

44 (discussing how "labels matter" and that "we communicate far more about our condemnation of wrongdoing when we call conduct criminal").

140 While the need for societal healing has not been addressed in prior accounts of corporate criminal liability, there is a substantial body of literature regarding the societal need for accountability in the transition from oppressive political regimes. See, e.g., Jon Elster, Closing the Books: Transitional Justice in Historical Perspective (2004) (defining and discussing transitional justice); MARTHA MinOW, BetweEN Vengeance and Forgiveness: Facing History After Mass GenOcide and Mass VIOLENCE (1999) (exploring societal responses to mass violence during transition to less oppressive regimes).

141 See, e.g., Robert J. Sampson, The Community, in CRIME: Public POLICIES FOR Crime Control 193, 203 (James Q. Wilson \& Joan Petersilia eds., 1995) (asserting that empirical studies, although limited in number, consistently show that "crime does in fact undermine the social and economic fabric of urban areas").

142 Dan M. Kahan, Social Meaning and the Economic Analysis of Crime, 27 J. LEGAL STUD. 609, 61819 (1998) ("Punishing corporations, just like punishing natural persons, is also understood to be the right way for society to repudiate the false valuations that their crimes express.").

143 Peter J. Henning, Corporate Criminal Liability and the Potential for Rehabilitation, 46 AM. CRIM. L. REV. 1417, 1426 (2009) (asserting that labeling misconduct "criminal" has social significance independent of the punishment imposed for the misconduct). 
use the proper terminology to describe the criminal conduct of corporations, we affirm societal values, enhance confidence in the justice system, and promote societal catharsis. ${ }^{144}$

Second, we foster societal catharsis by requiring corporations to accept responsibility for their criminal actions. A corporation that is charged with criminal activity must either admit guilt or face a jury trial. The "neither admit nor deny" settlements that are common in civil enforcement actions are not allowed in the criminal justice system except in the rare cases where "nolo contendere" pleas are permitted. ${ }^{145}$ By requiring admissions of guilt in cases resolved by guilty plea, the criminal justice system insists on acceptance of responsibility from corporations. It is difficult for us to move on from wrongdoing when the perpetrator refuses to take responsibility and apologize; societal catharsis is far easier when criminal activity gives way to admissions of wrongdoing. ${ }^{146}$ Perhaps this need might be addressed by prosecution of culpable individuals within the corporation - and guilty pleas or convictions at trial of those individuals. But individual culpability does not occur in a vacuum: the acts of individual corporate employees reflect the prevailing corporate culture and have aggregate effects on behalf of the corporation that must be acknowledged for societal catharsis to occur.

Third, criminal punishment involves condemnation and the imposition of blame in ways that other sanctions do not, which also facilitates societal catharsis after criminal activity. Professor Feinberg noted that part of the expressive function of criminal punishment was its statement of societal resentment. ${ }^{147}$ We should not underestimate the degree to which communities need to express their legitimate anger in the aftermath of criminal activity. Much as we want criminal defendants to admit their wrongdoing - or at least to be found guilty by a trial jury - we need express our indignation about how society

144 It merits emphasis that the criminal prosecution of corporations is not a substitute for the prosecution of culpable corporate officials. If only the corporation is prosecuted, despite clear evidence of individual wrongdoing, societal catharsis is undermined. See infra Part III for a discussion of the relationship between corporate and individual prosecution.

145 United States Attorneys' Manual \& 916.010 [hereinafter U.S. ATtORneys' MANUAL] (discussing the strict prosecutorial policies on nolo contendere).

146 The restorative justice movement is instructive on the benefits of admissions of wrongdoing for victims and offenders, as well as their communities. See generally Carrie Menkel Meadow, Restorative Justice: What Is It and Does It Work?, 3 ANNU. Rev. LAw Soc. SCI. 10.1 (2007) (defining and evaluating the effectiveness of restorative justice).

147 Feinberg, supra note 30, at 10001. 
has been wronged by criminal behavior. ${ }^{148}$ Expressions of anger are part of any healing process and help us move beyond pain. ${ }^{149}$ When there is no forum for expressing anger or resentment, those feelings must be repressed, and moving on is difficult. This is an area where the expressive function overlaps with retributive justifications; if the sanction for corporate crime is non-criminal, the punishment does not fit the crime, and societal catharsis is diminished and may not occur at all. As Paul Robinson explains, "society as well as the victim requires the just deserts punishment. Unless the punishment is imposed, a real feeling of incompleteness lingers, and there is a sense that justice has not been done. These feelings of incompleteness and sense of failed justice are held by those who witness or become aware of the original offense as well as by its victim." 150

Societal catharsis may seem attenuated from the purposes of criminal law and more akin to sociological or psychological concerns. In addition, to the extent that my focus is on how society recovers from corporate criminality, some critics of corporate criminal liability might argue that little is accomplished by expressing condemnation or imposing blame on inanimate objects like corporations. Albert Alschuler has suggested that condemning the corporation is akin to deodand, the ancient practice of punishing animals and inanimate objects. ${ }^{151}$ Professor Alschuler likens expression of anger toward corporations as similar to him yelling at his computer when it malfunctions. ${ }^{152}$ But, as noted in Part I, corporations both individually and in the aggregate have significant impacts in our communities, in our economies, and in our political system in ways that other inanimate objects do not. Viewed in isolation, societal expressions of anger about corporate misconduct may seem similar to frustration with an animal or rage against a machine, but indignation is both an appropriate response to corporate criminality and an expression of community values and what behavior is unacceptable.

148 See Judith Lewis Herman, Justice from the Victim's Perspective, 11 VIOLENCE AgAinst WOMEN 571, 578 (2005) (arguing that community resentment and indignation on behalf of victims is part of restorative justice process despite its traditional focus on defendants); see also Sepinwall, Guilty by Proxy, supra note 63, at 447 (arguing from a retributive perspective that corporate criminal liability can be appropriate way of discharging our indignation in the face of corporate wrongdoing).

149 See, e.g., Elisabeth Kubler Ross, On Death And Dying 44 (1969) (noting that anger is the second stage in the healing process after death occurs).

150 Paul H. Robinson et al., Why Do We Punish? Deterrence and Just Deserts as Motives for Punishment, 83 J. Personality \& SOC. Psychol. 284, 297 (2002).

151 Alschuler, Two Ways, supra note 20, at 137276.

152 Id. at 1373. 
In sum, we expect justice to be done when criminal wrongdoing occurs and no less so when the criminal violations are committed in the corporate context. Our faith in the criminal justice system depends on the belief that none of us are above the law and all of us are accountable for our actions. Nothing breeds cynicism or erodes public confidence more than perpetuating the sense that there is a different justice system for the rich and powerful, which under almost any definition would include corporations. Public cynicism is magnified even more by the perception that recent Supreme Court opinions afford free speech rights and religious liberties to corporations, ${ }^{153}$ yet corporations are not always held accountable for their misdeeds. If corporations may be persons for purposes of our constitutional liberties, they also should be persons for purposes of complying with the dictates of the criminal law. ${ }^{154}$ By holding corporations criminally liable and condemning their misconduct, we promote the rule of law, demonstrate that the criminal justice system can address corporate wrongdoing, and facilitate our societal ability to move on after crimes occur.

\section{THE MisunderstoOd RELATIONSHIP BETWEEN THE PROSECUTION OF CORPORATIONS AND INDIVIDUALS}

Although objections to corporate criminal prosecution involve different theoretical constructs, the critiques share one common ground: corporate crime should be addressed by prosecuting responsible individuals within corporations. ${ }^{155}$ Corporations face

153 See, e.g., Burwell v. Hobby Lobby Stores, Inc., 134 S. Ct. 2751 (2014) (holding that, as applied to closely held corporations, regulations requiring employers to provide female employees with no cost access to contraception violated the Religious Freedom Restoration Act); Citizens United v. Fed. Election Comm'n, 558 U.S. 310 (2010) (holding that under the First Amendment, the government cannot prevent corporate spending to advocate the election or defeat of a candidate, though corporations may not give money directly to campaigns).

154 A more nuanced reading of Citizens United is that the public has a right to hear all political speech eliding the question of whether corporations are persons that have free speech protections. See Amy J. Sepinwall, Citizens United and the Ineluctable Question of Corporate Citizenship, 44 ConN. L. REv. 575, 581 (2012). Likewise, the free exercise rights recognized in Hobby Lobby derive from the individual free exercise rights of the owners of closely held corporations. See Amy J. Sepinwall, Corporate Piety and Impropriety: Hobby Lobby's Extension of RFRA Rights to the For Profit Corporation, 5 HARV. BuS. L. REv. 173, 17576 (2015). But I would argue that the public perception that the decisions are broader and more protective of corporate interests fuels anger about lack of accountability for corporate crime and the sense that the law treats corporations more favorably.

155 See, e.g., Coffee, supra note 39, at 40711 (arguing that the individual must be targeted alongside the entity); Khanna, supra note 21 , at 1534 ("[C] orporate criminal 
criminal liability because the acts of their employees and agents are imputed to the corporation. From a retributive perspective, the culpable individuals deserve punishment, not the corporation that is incapable of moral wrongdoing. ${ }^{156}$ From a utilitarian perspective, the prospect of imprisonment is a greater deterrent than the possibility that the corporation may pay a monetary fine. ${ }^{157}$ In addition, according to both critiques, focusing on individual misconduct ensures that criminal prosecution is targeted to culpable individuals and not visited upon third parties, including non-culpable employees, shareholders, and perhaps customers. ${ }^{158}$

In this Part, I explain why the prosecution of corporations is warranted even when individuals are prosecuted. Unlike other scholars who support a dual approach to corporate crime, ${ }^{159}$ however, I go further and assert that corporations should be prosecuted for corporate wrongdoing even in cases where individuals should not or cannot be prosecuted. The need for criminal prosecution and the expressive function of punishment may be most apparent in "corporate-only" prosecutions.

\section{A. Charging Both the Corporation and Culpable Individuals}

The Justice Department announced in September 2015 that it would be intensifying its efforts to hold individuals accountable for corporate wrongdoing. ${ }^{160}$ I agree that culpable individuals should be prosecuted in the corporate context. There is no dispute that individuals can have moral culpability. It also is axiomatic that most corporate officials are more likely to be deterred by the possibility that their actions could result in individual culpability — to include jail time - than by concerns about organizational culpability. In the hundreds of

liability may continue to provide enforcement cost savings in situations in which pursuing managerial criminal liability is optimal.").

156 See supra Part I.A for a discussion of the retributive critique of corporate criminal liability.

157 See supra Part I.B for a discussion of the utilitarian critique of corporate criminal liability.

158 Coffee, supra note 39, at 40102.

159 See, e.g., id. at 410 ("[A] dual focus on the firm and the individual is necessary."); Brandon L. Garrett, The Corporate Criminal as Scapegoat, 101 VA. L. REV. 1789, 1795 (2015) [hereinafter Corporate Criminal as Scapegoat] (arguing that corporate prosecutions should be brought in conjunction with charges against individuals).

160 See Memorandum from Sally Q. Yates, Deputy Attorney Gen., U.S. Dep't of Justice, Individual Accountability for Corporate Wrongdoing (Sept. 9, 2015) [hereinafter Yates Memo], available at http://www.justice.gov/dag/file/769036/download. 
corporate cases that I supervised or prosecuted during my seventeen years at the Justice Department, it always was a priority to identify individuals who were appropriate to prosecute, if the law and the facts supported criminal charges. In every indictment review, we assessed the evidence against the individuals involved in corporate wrongdoing and evaluated whether their individual conduct warranted prosecution.

But I reject the notion that prosecutors confronted with corporate wrongdoing must choose between prosecuting corporations and prosecuting individuals. Corporate crime has far-reaching and debilitating effects on our communities. As noted throughout this article, some corporate crimes cause catastrophic harm, such as the Gulf oil spill, the Upper Big Branch Mine tragedy, and the Enron case. ${ }^{161}$ Other corporate crimes may be less harmful individually but cause significant harm in the aggregate. All corporate crime undermines the fair competition at the heart of our economic system - and all corporate crime involves a violation of the corporation's duty to conduct its affairs in a lawful manner.

Given the pernicious harm and lawless conduct inherent in corporate crime, both corporations and individuals should be held accountable when wrongdoing occurs in the corporate setting. At a minimum, prosecutors and investigators should have the ability to consider charges against both corporations and individuals, so that the full range of enforcement options are available to address corporate misconduct. The Justice Department prosecution guidelines recognize these principles, making clear that there is no binary choice to be made between prosecuting corporations and prosecuting individuals when corporate crime occurs. "Prosecution of a corporation is not a substitute for the prosecution of criminally culpable individuals within or without the corporation." 162 There is no reason that we should limit societal tools to fight corporate crime, in essence taking on the task with one hand tied behind our backs.

The prosecution of both corporations and individuals offers benefits beyond those conferred by using all available resources to combat corporate crime. The prosecution of corporations addresses the wrongdoing of the corporation as a whole; the prosecution of individuals addresses her contribution to the larger corporate

161 In the Enron case, thousands of employees lost retirement savings. Richard A. Oppel, Jr., Employees' Retirement Plan Is a Victim as Enron Tumbles, N.Y. TIMES (Nov. 22, 2001), http://www.nytimes.com/2001/11/22/business/employees retirement plan is a victim as enron tumbles.html.

162 U.S. ATtORnEYS' MANUAL, supra note 145, § 928.210. 
problem. The prosecution of the corporation seeks to change corporate behavior in the future; the prosecution of the individual is directed at the employee's behavior in the future. The prosecution of the corporation condemns and assigns blame to the corporate culture and the misplaced corporate priorities that led to criminal conduct by the employee; the prosecution of the individual addresses the poor choices made by the individual corporate employee.

The only circumstances where I would suggest that prosecutors might be expected to choose between the prosecution of a corporation and the prosecution of an individual would be cases involving small family-owned companies or sole proprietorships. In those prosecutions, where there is effectively an identity between the corporation and the individual, I would prosecute the individual and decline to prosecute the corporation. ${ }^{163}$ I say so because there is nothing to be gained in cases involving so-called "Mom and Pop" companies and sole proprietorships - no retributive, utilitarian, or expressive purpose - that is not already achieved by prosecuting the owner of the company. ${ }^{164}$

In cases involving larger corporations, the calculus shifts, because there is a corporate entity that is larger and distinct from its individual members, with influence over the conduct of corporate affairs that even a senior management official is unlikely to possess. In the rare case where a larger corporation is the alter ego of its board chairman or its chief executive officer - and where that person carried out unlawful activity on behalf of the corporation - it theoretically might be possible to satisfy the goals of criminal prosecution by charging only the chairman or chief executive officer. In all other cases, as explained in greater detail below, I would argue that charges must be brought against the corporation and responsible individuals - and that charges should be brought against the corporation even when no individual can or should be charged.

163 Buell, Blaming Function of Entity Criminal Liability, supra note 25, at 535 n.263 ("It is hard to see the justification for entity criminal liability in cases of sole or near sole proprietorships. Assuming that entity liability is implicated because of the owner's crime, the entity effectively represents just another personal asset of the offender.").

164 Accord Lynch, supra note 49, at 51 (small and closely held corporations are "unlikely to be perceived by the public as having any separate personality" from their individual owners and managers). Stated differently, in Mom and Pop companies there is no corporate culture independent of the owners nor corporate blameworthiness independent of the culpability of the owners. See id. 


\section{B. Charging the Corporation and Management Officials}

The Justice Department corporate prosecution principals make management involvement in misconduct a key factor in the exercise of prosecutorial discretion involving corporations. ${ }^{165}$ An argument could be made that prosecution of the corporation is not needed if senior officials have been prosecuted; the corporation will be forever changed by those individual prosecutions and civil enforcement may be sufficient against the corporation. Yet where senior officials are involved, the culpability of the corporation qua corporation appears greatest; it would seem incongruous to decline criminal prosecution of the corporation when misconduct reached senior management.

In Part II, I referenced the prosecution of McWane, Inc., which occurred during my tenure as Chief of the Environmental Crimes Section at the Justice Department. ${ }^{166}$ In the McWane prosecutions, we brought charges against five McWane subsidiaries: Atlantic States Cast Iron Pipe Company, McWane Cast Iron Pipe Company, Pacific States Cast Iron Pipe Company, Tyler Pipe, and Union Foundry. ${ }^{167}$ Three of the subsidiaries pleaded guilty; two of the subsidiaries were convicted after trials. ${ }^{168}$ We also prosecuted eleven management officials at three of the McWane subsidiaries; eight were convicted at trial, and one pleaded guilty. ${ }^{169}$ The ability to bring charges against the companies and the management of the McWane facilities addressed years of criminal violations of the environmental laws and the worker safety laws at McWane facilities. ${ }^{170}$ It was essential to hold criminally responsible the management officials who carried out the wrongdoing. But it was not a coincidence that there were violations at five separate McWane facilities. There was a larger corporate culture responsible for the crimes at McWane, ${ }^{171}$ which would not have been addressed

165 U.S. ATtORNEYS' MANUAL, supra note 145, § 928.500 (containing a section entitled "Pervasiveness of Wrongdoing Within the Corporation").

166 See supra notes 9394 and accompanying text.

167 Uhlmann, Prosecuting Worker Endangerment, supra note 85, at 7.

168 Id.

169 James Sandler et al., The McWane Prosecutions, FrontLine (Feb. 5, 2008), available at http://www.pbs.org/wgbh/pages/frontline/mcwane/etc/prosecutions.html.

170 Id.; see David Barstow \& Lowell Bergman, Criminal Inquiry Under Way at Large Pipe Manufacturer, N.Y. Times (May 15, 2003), http://www.nytimes.com/2003/05/ 15/us/criminal inquiry under way at large pipe manufacturer.html.

171 Uhlmann, Prosecuting Worker Endangerment, supra note 85, at 7; see also A Dangerous Business: Two Companies, Two Visions, FrontLine (Jan. 2003) [hereinafter Two Companies], http://www.pbs.org/wgbh/pages/frontline/shows/workplace/mcwane/ two.html (describing the "McWane Way"). 
without criminal charges and convictions of the five McWane subsidiaries.

I also have referenced several times the Upper Big Branch Mine tragedy, where twenty-nine workers died because of willful violations of the Mine Safety Act. In that case, four Massey Corporation officials were convicted and sentenced to jail time. ${ }^{172}$ In addition, prosecutors charged Don Blankenship, the chief executive officer of Massey and allegedly the prime orchestrator of the criminal conduct at the company. ${ }^{173}$ According to the indictment, Blankenship was the kind of "iron-fisted" chief executive officer who could be charged in lieu of the corporation. Prosecutors alleged that Blankenship controlled every aspect of Massey's operation in almost despot-like fashion. ${ }^{174}$ Blankenship was convicted at trial of conspiracy to violate the Mine Safety Act and was sentenced to serve one year in prison. ${ }^{175}$

Still, I would argue that Massey also should have been prosecuted, given the deadly harm caused by their crimes and the hundreds of violations of federal mining laws committed at their mines. ${ }^{176}$ Massey was a notorious violator of mine safety and environmental laws. ${ }^{177}$ It flouted the rule of law and deserved societal condemnation and blame for the horrors it wrought as a company. Instead, Massey's new owners were allowed to enter a non-prosecution agreement that sent a demoralizing message about how the government viewed the misconduct that led to tragedy at the Upper Big Branch mine. ${ }^{178}$

172 Convictions Related to the Upper Big Branch Mine, Charleston GazetTE Mail (Nov. 13, 2014), http://www.wvgazettemail.com/article/20141113/GZ01/141119614/1460.

173 Indictment, United States v. Blankenship, No. 5:14 cr 00244 (S.D. W. Va., Nov. 13, 2014) [hereinafter Blankenship Indictment]; see Trip Gabriel, Ex Executive Donald Blankenship Is Indicted in Disaster at Coal Mine, N.Y. TIMES, Nov. 14, 2014, at A12.

174 See Blankenship Indictment, supra note 173.

175 Alan Blinder, Mine Chief Is Sentenced in Conspiracy Over Safety, N.Y. TimES, Apr. 7, 2016, at A12; Alan Blinder, Ex Chief of Massey Energy Guilty of Misdemeanor After Mine Disaster, N.Y. TIMES, Dec. 4, 2015, at A18.

176 MSHA REPORT, supra note 137, at 2, 12; see also Uhlmann, 29 Dead Miners, supra note 3 (describing finding by MSHA that Massey's "unlawful policies and practices" were the "root cause" of the nation's worst mining disaster in 40 years).

177 Uhlmann, Erosion of Corporate Criminal Liability, supra note 1, at 129597.

$178 \mathrm{Id}$. at 1300 ("[O]n the same day that MSHA issued a 972 page investigative report that lay bare the lawlessness that occurred within Massey, the Justice Department announced that it was entering a non prosecution agreement with the new owners of Massey and therefore would not bring criminal charges against the company."). 


\section{Charging the Corporation and Lower-Level Supervisors}

The need for corporate prosecution may be even greater in cases where only lower-level supervisors can be charged with wrongdoing. In cases where the only individuals who can be charged are at low levels within the corporate hierarchy, the weight of criminal prosecution falls on individuals who, while culpable, had no control over the corporate policies that led to criminal activity. The Gulf oil spill provides a classic example. There is widespread agreement that the Gulf oil spill involved a failure of corporate culture of epic proportions. BP had a corporate culture that promoted risk-taking in its drilling operations, at the expense of environmental protection and worker safety; the corporate policies and priorities that fostered that culture were determined to be the root cause of the spill. ${ }^{179}$ Yet the only individuals who had enough personal involvement in the spill to be charged with crimes - the well site leaders who were the top "company men" on the Deepwater Horizon drilling rig - had no role in the development of BP's policies or its corporate culture. ${ }^{180}$

I have questioned whether the BP well site leaders should have been charged criminally in the Gulf oil spill, which effectively made the statement that they personally were responsible for thirteen deaths and catastrophic environmental harm in an oil spill caused by corporate failure far beyond their control. ${ }^{181}$ Perhaps there was sufficient evidence of the culpability of the well site leaders to justify criminal charges against them. Indeed, the government alleged in the superseding indictment that the defendants "negligently and grossly

179 NAT'L COMM'N ON THE BP DeEPWATER Horizon OIL SPILl \& OFFSHORE Drilling, Deep Water: The Gulf Oil Disaster and the Future of OfFshore Drilling 12226 (2011), available at https://www.gpo.gov/fdsys/pkg/GPO OILCOMMISSION/pdf/GPO OILCOMMISSION.pdf.

180 See Christina Bergmann, Oil Giant BP Faces Record Fine, DeutsChe Welle (Nov. 17, 2012), http://www.dw.de/oil giant bp faces record fine/a 16386244 ("'This was a corporate culture run amok.' . . . 'There were issues with this well for weeks and months prior to the blowout. . . Y You obviously can't blame all of that on the rig supervisors."'); Tom Fowler \& Russell Gold, Engineers Deny Charges in BP Spill, WALl ST. J. (Nov. 18, 2012), http://www.wsj.com/articles/SB10001424127887323622904578127173280594296 ("It raises the question if it's fair to charge these individuals who had no influence or authority over these policies and this culture."); Ameet Sachdev, BP Criminal Liability Influenced by 1985 Chicago Case, CHI. TRIB. (Nov. 18, 2012), http://articles.chicagotribune.com/2012 11 18/business/ct biz 1118 corporate mal 201211181 deepwater horizon workplace safety gary leviton/2 ("Every study, even the government's own investigations, have concluded that the spill occurred because of corporate management failures' .... 'It's a fair question whether there are individuals higher up in the corporate chain of command who were involved in decisions that led to the spill."').

181 See Fowler \& Gold, supra note 180. 
negligently failed to maintain control of the Macondo well." 182 Or the defendants may have been scapegoats in a case where the government was determined to find individual culpability for the worst environmental disaster in United States history.

In December 2015, the Justice Department dropped the remaining manslaughter charges against the BP well site leaders, leaving only a charge of negligent violation of the Clean Water Act. ${ }^{183}$ One of the well site leaders, Donald Vidrine, pleaded guilty to the Clean Water Act charge, which is a misdemeanor, and is awaiting sentencing. ${ }^{184}$ The other well site leader, Robert Kaluza, was acquitted at trial in February 2016.185 But even if the government had successfully prosecuted both of the well site leaders, it would have been wrong to hold only those two individuals criminally responsible for the spill and the deaths that resulted. The government properly charged BP - as well as Transocean, the drilling company - with criminal violations of the Clean Water Act for their corporate negligence. ${ }^{186}$ To proceed otherwise would have indulged the counter-factual that only two relatively low-level supervisors were responsible for the spill despite abundant evidence of corporate failings in which they had no part. These were corporate crimes; prosecutors properly charged BP and Transocean. ${ }^{187}$

182 Superseding Indictment at 6, United States v. Kaluza, No. 12265 (Nov. 14, 2012).

183 Margaret Cronin Fisk \& Laurel Brubaker Calkins, BP Well Site Managers' Oil Spill Manslaughter Case Dropped, BLOOMBERG BUS. (Dec. 2, 2015), http://www.bloomberg.com/ news/articles/2015 12 02/bp well site leaders win dismissal of u s manslaughter case.

184 Id.

185 Aruna Viswanatha, US Bid to Prosecute BP Staff in Gulf Oil Spill Falls Flat, WaLL ST. J. (Feb. 27, 2016), http://www.wsj.com/articles/u s bid to prosecute bp staff in gulf oil spill falls flat 1456532116 .

186 Summary of Criminal Prosecutions, U.S. Envtl. Protection Agency, http://cfpub.epa.gov/compliance/criminal prosecution/index.cfm?action=3\&prosecution summary id $=2468$ (last visited Feb. 6, 2016) (describing the criminal proceedings brought against BP Exploration and Production and Transocean, and their subsequent guilty pleas).

187 A different scenario might be presented if criminal activity occurred despite the best efforts of the corporation to comply with the law. If the corporation had an exemplary compliance program and individuals engaged in wrongdoing despite the fact that the company conducted its affairs in a manner that we would consider normatively desirable, it might be appropriate to prosecute only the culpable individuals. See U.S. ATTORNEYS' MANUAL, supra note 145, \& 928.500 ("[I]t may not be appropriate to impose liability upon a corporation, particularly one with a robust compliance program in place, under a strict respondeat superior theory for the single isolated act of a rogue employee.") In my experience, however, the existence of such "rogue employees" is usually attributable to shortcomings in the company's training, supervision, or compliance programs, despite fervent claims to the contrary from 


\section{Charging the Corporation and No Individuals}

The need for corporate prosecution may be greatest in the most criticized - and most misunderstood - cases: prosecutions where no individuals are charged. Some of the concerns about corporate-only prosecutions are valid. Prosecutors should not pursue corporate-only prosecutions in exchange for not prosecuting individuals, ${ }^{188}$ which is a misuse of prosecutorial discretion and creates the appearance that corporations can buy-off charges against corporate officials. Nor should prosecutors resolve cases with corporate-only prosecutions because they are unwilling to invest the time and effort required to prosecute individuals. Likewise, prosecutors should not bring corporate-only charges based on weak evidence that corporations might not contest because of the difficulty of defending corporate cases or to avoid the scrutiny of a trial.

In my experience, however, most corporate-only prosecutions occur because, while individuals could be charged, prosecution of those individuals is not appropriate as a matter of prosecutorial discretion. As a threshold matter, prosecutors only should consider criminal charges if there is sufficient evidence to prove guilt beyond a reasonable doubt, and if they are confident that they can address any legal issues and defenses that may be raised by the defendant. ${ }^{189}$ But the decision to charge does not end with an evaluation of the evidence and possible defenses. Prosecutors also must consider principles of fairness and justice to ensure that charges are reserved for the conduct and defendants that are culpable. ${ }^{190}$

In the regulatory crime context, significant violations could occur at a company where the only individuals with sufficient knowledge to be

defense counsel.

188 See Yates Memo, supra note 160, at 5 ("Absent extraordinary circumstances, no corporate resolution will provide protection from criminal or civil liability for any individuals."). But see Garrett, Corporate Criminal as Scapegoat, supra note 159, at 1791 (finding that, between 2001 and 2014, charges were brought against individuals in only $34 \%$ of deferred and non prosecution agreements).

189 See U.S. ATtORNEYS' MANUAL, supra note 145, \& 927.220 (advising a prosecutor to initiate charges only if "the admissible evidence will probably be sufficient to obtain and sustain a conviction"); David M. Uhlmann, Prosecutorial Discretion and Environmental Crime, 38 HARV. ENVTL. L. REV. 159, 164 (2014) [hereinafter Prosecutorial Discretion] (arguing that "prosecutors should only bring charges if there is sufficient evidence to prove each element of the offense beyond a reasonable doubt").

190 Uhlmann, Prosecutorial Discretion, supra note 189, at 215 ("Prosecutors thus have reserved criminal prosecution for culpable conduct and avoided charges based on technical violations or when defendants acted in good faith."). 
charged criminally are low-level employees - not even supervisors who never received sufficient training or the resources necessary to comply with the law. Their supervisors, who might make better targets based on their higher status within the company, may have had no better training and no more resources. Yet higher up the corporate ladder, where responsibility for poor training and inadequate resources resides, management officials may not have enough knowledge to be charged with crimes. In those cases, where crimes occurred and there is a need for accountability, condemnation, and societal catharsis, it may not be fair or just to charge the employees or even their immediate supervisors. ${ }^{191}$ Instead, charges should be brought against the corporation that did not provide the training or the resources that its employees needed to meet the company's legal obligations.

Other corporate-only prosecutions occur because it is not possible to prosecute individuals. As the First Circuit recognized in Bank of New England, 192 there are cases where corporate crime occurs but it is not possible to develop sufficient evidence against individuals to charge them with wrongdoing. Corporations compartmentalize knowledge and subdivide operational duties to promote corporate efficiency. ${ }^{193}$ In cases like Bank of New England where the corporate structure makes it impossible to charge individuals, there still is a societal need to address the wrongdoing. In those cases, the only potential defendant is the corporation. ${ }^{194}$ Prosecutors must choose between prosecuting the offending corporation and refusing to bring criminal charges despite clear evidence of corporate wrongdoing.

In two of the McWane prosecutions, Tyler Pipe and Union Foundry, there was a similar problem with charging individuals. At both Tyler Pipe and Union Foundry, a worker died because of willful violations of the Occupational Safety and Health Act ("OSH Act"). ${ }^{195}$ But the $\mathrm{OSH}$ Act only allows criminal charges to be brought against the employer, which in both cases was the McWane subsidiary where the

191 Lynch, supra note 49, at 52 (stating that a corporate prosecution is appropriate "where the individuals who can be punished are insufficiently important to bear the weight of stigma appropriately attaching to the harmfulness or offensiveness of the wrong").

192 United States v. Bank of New England, 821 F.2d 844 (1st Cir. 1987).

193 See id. at 856 ("Since the Bank had the compartmentalized structure common to all large corporations, the court's collective knowledge instruction was not only proper but necessary.").

194 Lynch, supra note 49, at 52 (stating that a corporate prosecution is appropriate "when no individual can be proven culpable").

19529 U.S.C. \& 666 (2012). 
deaths occurred.196 The Justice Department faced a choice: either prosecute Tyler Pipe and Union Foundry for the worker deaths or no criminal charges would be brought. Absent criminal prosecution, Tyler Pipe and Union Foundry would have faced only modest administrative fines under the OSH Act. ${ }^{197}$ The Justice Department therefore prosecuted McWane and obtained a $\$ 4.25$ million criminal penalty in the Tyler Pipe case and a $\$ 3.5$ million criminal penalty in the Union Foundry case, in addition to far-reaching compliance agreements for improvements at both facilities. 198

I would suggest that corporate-only prosecutions like those involving Tyler Pipe and Union Foundry may provide the best examples of why criminal prosecution of corporations is so essential. Both cases involved tragic worker deaths at facilities that had years of worker safety violations. The conduct was egregious enough to deserve criminal sanction, and prior fines had not convinced the companies to comply with the law. 199 Corporations exist for lawful purposes only, not to engage in the rampant misconduct that took place at McWane's plants.

As I explained in Part I, there are retributive and utilitarian justifications for corporate criminal prosecution, particularly in cases like Tyler Pipe and Union Foundry. But the expressive function of criminal prosecution is highlighted most by the Tyler Pipe and Union Foundry cases. Criminal prosecution of Tyler Pipe and Union Foundry upheld the rule of law at facilities where it was under siege and made clear that companies are expected to provide a safe work place for their employees. Criminal prosecution also ensured societal condemnation of conduct at McWane that was reprehensible. McWane needed to be held accountable for a deplorable corporate culture - "the McWane Way" - that allowed worker safety and environmental violations at multiple McWane facilities, in Alabama, New Jersey, Texas, and Utah. 200

196 Id.

197 Under the OSH Act, the maximum administrative penalty for willful or repeated violations is $\$ 70,000$ per violation. 29 U.S.C. $\$ 666(a)$ (2012).

198 Press Release, U.S. Dep't of Justice, Division of McWane, Inc. Sentenced to \$4.25 Million in Criminal Fines \& Community Service Related to Worker Safety, Environmental Crime (Sept. 7, 2005), available at http://www.justice.gov/archive/ opa/pr/2005/September/05 enrd 458.html.

199 Barstow \& Bergman, supra note 170 ("The company has been cited for more than 400 safety violations and 450 environmental violations since 1995 . While the company has paid roughly $\$ 10$ million in fines and penalties, no McWane official has ever gone to jail for these violations.").

200 See Two Companies, supra note 171 (describing the "McWane Way"). 
Without criminal charges against the corporate defendants in Tyler Pipe and Union Foundry, the worker deaths that occurred at the McWane facilities would not have been crimes at all. There would have been no accountability, no justice for the families of the victims, and no opportunity for catharsis of any kind. Anything less than criminal prosecution of the McWane facilities would have expressed the wrong societal values: that worker deaths, even when they occur because of willful violations of the law, are just a cost of doing business; that the most egregious safety violations do not warrant societal condemnation; and that the suffering of McWane's victims were just a matter for monetary penalties and tort claims. For the families of those victims and for the communities where McWane was a prominent company operating outside the law, justice required the strongest possible condemnation of McWane and admissions by the company that it had committed crimes. The collective sense that justice was served in Alabama and Texas - and in the other states where McWane routinely broke the law - was an essential ingredient for the affected communities to heal and face the future more confident that corporate lawlessness would not be tolerated.

\section{CONCLUSION}

Although most companies take their legal obligations seriously and contribute in positive ways to their communities, corporate crime occurs with alarming regularity. When corporations engage in criminal activity, their misconduct must be addressed by the criminal justice system. Corporate crime harms our economy, our workers, and the environment. Corporate crime has moral content, insofar as corporations have internal decision structures that allow them to act intentionally and therefore morally. Corporations have cultures that influence the conduct of individual corporate officials and a separate identity that may be deserving of punishment. From a utilitarian perspective, criminal prosecution is a stronger deterrent for corporate misconduct than civil enforcement and more likely to change the corporate cultures that foster criminal behavior.

Corporate crime warrants the condemnation that the criminal law provides. The prosecution of corporations and culpable individuals within offending companies is necessary to uphold the rule of law, validate the choices of law-abiding companies, and provide accountability. Together those values contribute to our sense that justice has been done when crime occurs, which enhances trust in the legal system, provides the opportunity for societal catharsis that is 
essential to healing, and allows us to move forward in the aftermath of criminal activity.

We must hold corporations accountable even when individual defendants cannot be prosecuted - indeed, especially when individuals cannot be prosecuted - lest we send the message that corporations are above the law. When corporations face no consequences for their criminal behavior, cynicism increases about the role of corporations in our society. When corporations engage in misconduct that is criminal, we must be prepared to make clear that their conduct is criminal and uphold the core societal values expressed by the criminal law. 